\title{
Natural and anthropogenic trace metals in sediments of the Ligurian Sea (Northwestern Mediterranean)
}

\author{
Lars-Eric Heimbürger ${ }^{\mathrm{a}, \mathrm{b}, \mathrm{c},{ }^{\star}}$, Daniel Cossa ${ }^{\mathrm{a}}$, Benoit Thibodeau ${ }^{\mathrm{d}}$, Alexis Khripounoff ${ }^{\mathrm{e}}$, \\ Virginie Mas $^{\mathrm{e}}$, Jean-François Chiffoleau ${ }^{\mathrm{f}}$, Sabine Schmidt $^{\mathrm{g}}$ and Christophe Migon ${ }^{\mathrm{b}, \mathrm{c}}$
}

\footnotetext{
a IFREMER, Centre de Méditerranée, BP 330, F-83507 La Seyne-sur-Mer, France

b Université Pierre et Marie Curie (UPMC), UMR 7093, Observatoire océanologique de Villefranche-sur-Mer, F06234, Villefranche-sur-Mer, France

${ }^{\mathrm{C}}$ CNRS/INSU, UMR 7093, Laboratoire d'Océanographie de Villefranche, F-06234, Villefranche-sur-Mer, France

${ }^{\mathrm{d}}$ GeOTOP, Université du Québec à Montréal, CP 8888, Succ. Centre Ville, Montréal (QC), H3C 3P8 Canada

e IFREMER, Centre de Brest, BP 70, F-29280 Plouzané, France

${ }^{f}$ IFREMER, Centre de Nantes, BP 21115, F-44311 Nantes, France

${ }^{9}$ CNRS/Insu, UMR 5805, Université Bordeaux, F-33405 Talence, France
}

*: Corresponding author : $\underline{\text { heimburger@get.obs-mip.fr }}$

\begin{abstract}
:
The magnitude and the chronology of anthropogenic impregnation by $\mathrm{Hg}$ and other trace metals of environmental concern $(\mathrm{V}, \mathrm{Cr}, \mathrm{Ni}, \mathrm{Cu}, \mathrm{Zn}, \mathrm{Ag}, \mathrm{Cd}$ and $\mathrm{Pb}$, including its stable isotopes) in the sediments are determined at the DYFAMED station, a site in the Ligurian Sea (Northwestern Mediterranean) chosen for its supposed open-sea characteristics. The DYFAMED site (VD) is located on the right levee of the Var Canyon turbidite system, at the end of the Middle Valley. In order to trace the influence of the gravity current coming from the canyon on trace metal distribution in the sediment, we studied an additional sediment core (VA) from a terrace of the Var Canyon, and material collected in sediment traps at the both sites at $20 \mathrm{~m}$ above sea bottom. The patterns of $\mathrm{Hg}$ and other trace element distribution profiles are interpreted using stable $\mathrm{Pb}$ isotope ratios as proxies for its sources, taking into account the sedimentary context (turbidites, redox conditions, and sedimentation rates). Major element distributions, coupled with the stratigraphic examination of the sediment cores point out the high heterogeneity of the deposits at VA, and major turbiditic events at both sites. At the DYFAMED site, we observed direct anthropogenic influence in the upper sediment layer $(<2 \mathrm{~cm})$, while on the Var Canyon site (VA), the anthropization concerns the whole sedimentary column sampled $(19 \mathrm{~cm})$. Turbiditic events superimpose their specific signature on trace metal distributions.

According to the ${ }^{210} \mathrm{~Pb}_{\mathrm{xs}}$-derived sedimentation rate at the DYFAMED site $\left(0.4 \mathrm{~mm} \mathrm{yr}^{-1}\right)$, the $\mathrm{Hg}$ enriched layer of the top core corresponds to the sediment accumulation of the last 50 years, which is the period of the highest increase in $\mathrm{Hg}$ deposition on a global scale. With the hypothesis of the absence of significant post-depositional redistribution of $\mathrm{Hg}$, the $\mathrm{Hg} / \mathrm{C}_{\text {org }}$ ratio changes between the surface and below are used to estimate the anthropogenic contribution to the $\mathrm{Hg}$ flux accumulated in the sediment. The Hg enrichment, from pre-industrial to the present time is calculated to be around $60 \%$, consistent with estimations of global Hg models. However, based on the chemical composition of the trapped material collected in sediment traps, we calculated that epibenthic mobilization of $\mathrm{Hg}$ would reach $73 \%$. Conversely, the $\mathrm{Cd} / \mathrm{C}_{\text {org }}$ ratio decreases in the upper $5 \mathrm{~cm}$, which may reflect the recent decrease of atmospheric $\mathrm{Cd}$ inputs or losses due to diagenetic processes.
\end{abstract}

Keywords: Marine sediments, sediment traps, Canyon, Mercury, Trace metals, lead isotopes, geochronology 


\section{Introduction}

In contrast to other trace metals (TMs) of environmental concern, $\mathrm{Hg}$ can be singled out as a global (or at least hemispheric) contaminant, since it has a long residence time in the atmosphere (0.5-2 years; (Schroeder and Munthe, 1998), resulting in its ubiquitous distribution. Indeed, global $\mathrm{Hg}$ emissions have substantially increased during the past 150 years (e.g. Mason et al., 1994), and there is evidence for the impact of atmospherically transported anthropogenic $\mathrm{Hg}$ emissions in remote regions of the globe (Fitzgerald et al., 1998). This impact is detectable in lake sediment and peat bog records of remote regions, which have been revealed as reliable archives for estimating historical $\mathrm{Hg}$ accumulation (e.g. Muir et al., 2009). In spite of the difficulty of establishing homogeneous geochemical $\mathrm{Hg}$ backgrounds, the relative importance of natural versus anthropogenic sources of this TM on a global scale has been documented in peat bogs (Shotyk et al., 2003) and lake sediment achieves (Swain et al., 1992).

In the marine environment, most investigations have been made on continental shelves (e.g. Canals et al., 2006; Palanques et al., 2008; Costa et al., 2011). There, anthropogenic and natural Hg inputs are accumulated in sediment and concentrations above the natural background levels have been observed (e.g. GESAMP, 1990; Gobeil and Cossa, 1993). In the open ocean, several natural processes may alter $\mathrm{Hg}$ levels in sediments, including sub-marine hydrothermal activity (Boström and Fisher, 1969; Grousset and Donard, 1984), high organic matter flux events resulting in organic rich sediments such as sapropel (Gehrke et al., 2009), turbidites (Mercone et al., 1999), or diagenetic redistribution of $\mathrm{Hg}$ at the oxic/post-oxic boundary.

In the Mediterranean Sea, very few studies address the $\mathrm{Hg}$ transfer, deposition and accumulation in open sea sediments (Mercone et al., 1999; Ogrinc et al., 2007; Gehrke et al., 2009). Cossa and Coquery (2005) addressed the question of $\mathrm{Hg}$ mobilization and burial in the abyssal sediments at a site in the middle of the Algero-Provencal sub-basin. In spite of the observation of a two-fold decrease of organic carbon $\left(\mathrm{C}_{\text {org }}\right)$ content in sediment between surface and $5 \mathrm{~cm}$-depth, which supports the hypothesis of a diagenetic post-depositional $\mathrm{Hg}$ redistribution, the authors assumed the presence of traces of anthropogenic $\mathrm{Hg}$ contamination in the surface sediments.

In the Northwestern Mediterranean basin, the DYFAMED site has been chosen as an example of an open ocean site, supposedly isolated from major lateral inputs from the continent by the persisting Ligurian current (Béthoux et al., 1988; Sournia et al., 1990; Schmidt and Reyss, 1996). The role of the sediment as an archive for the deposition of contaminants at this site has received little attention until recently, when Martin et al. (2009) reported on sediment concentration of $\mathrm{Cr}, \mathrm{Ni}, \mathrm{Cu}, \mathrm{Zn}$ and $\mathrm{Pb}$. The results of their sediment core study, compared to atmospheric data (Migon et al., 2008), suggest that atmospheric deposition is the main entrance route of anthropogenic TMs accumulated in the recent sediments. However, occasional lateral advection of sediment by currents and sediment gravity flow may also contribute to the pre-industrial accumulation of TMs. Indeed, Miquel et al. (1994) noted that $2100 \mathrm{~m}$ sediment traps at the DYFAMED site received amounts of material in excess of those collected at depth of 200 and $1000 \mathrm{~m}$. The site is in fact located in an active sedimentary system, which may receive material via sediment gravity flows (Migeon et al., 2006; Khripounoff et al., 2009) and deep water formation during winter convection (Martin et al., 2010).

We present here the first $\mathrm{Hg}, \mathrm{Ag}$, and Cd profiles in sediment at the DYFAMED site (VD). In order to trace the influence of the gravity current, which might be an additional source for TMs in the VD sediment core, we studied an additional sediment core (VA), sampled within the Var Canyon, on a terrace of the Upper Valley, and material collected in sediment traps along the channel. Complementary results on $\mathrm{Cr}, \mathrm{Ni}, \mathrm{Cu}, \mathrm{Zn}$ and $\mathrm{Pb}$ (with its stable isotopes) allow comparison with previous measurements by Martin et al. (2009). However, before interpreting sedimentary TM profiles in term of anthropization, a careful examination of the geochemical context of the sediment is required. Changes in mineralogy, granulometry, sedimentary conditions, physical or biological mixing, and early diagenesis processes can alter TM profiles. Thus, here, we will first study the sedimentary context before examining the anthropization degree, pathways, sources of TMs and their changes with time. 


\section{Material and methods}

\subsection{Description of the sampling sites}

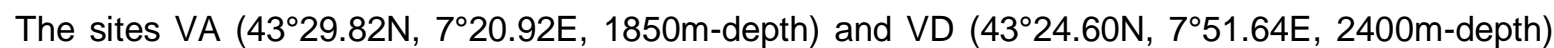
are located after the confluence of the Var and Paillon Canyons, and at the DYFAMED site, respectively (Fig. 1). The VA is located on a terrace of the Var Canyon and VD in the eastern part of the Var Sedimentary Ridge, corresponding to the enlarged right levee of the turbidite system at the end of the Var Middle Valley (Mas et al., 2010).

The Var Canyon is connected to the Var River through a narrow shelf with a steep margin. These features, together with the flush flood regime of the Var River, promote the formation of sediment gravity flows, which may export material into the deep basin (Mulder et al., 1997; Migeon et al., 2006; Khripounoff et al., 2009; Mas et al., 2010). Sediment transfer covers low-magnitude, high-frequency (yearly) turbid plumes to turbidity currents generated by large slope failures.

The DYFAMED site, between Nice and Calvi, is supposedly protected from lateral inputs in the central part of the Ligurian Sea (Béthoux et al., 1988; Sournia et al., 1990). Suspended particles in the water column originate from atmospheric deposition (Migon et al., 2002) and from primary production (Marty and Chiavérini, 2002; Marty et al., 2002). Their vertical transport derives from intense episodic blooms, without any direct influence of continental inputs. However, the deposited sediment may be partially fed by advection of the turbidity current, mainly from the Var Canyon (Martin et al., 2009), since it is located within the Middle Valley of the Var Canyon turbidite system, on the lowest part of its right-hand side levee, elevated at less than $30 \mathrm{~m}$ above the channel floor.

\subsection{Sampling and chemical analysis}

Interface cores were collected using a multi-corer at the sites VA and VD during the cruise "Envar-4" on board of the R/V Suroît in September 2006 (Khripounoff et al., 2009). The cores of 19 and 17cmlength from VA and VD respectively, were sliced aboard the vessel, immediately after sampling (each $0.5 \mathrm{~cm}$ from the water-sediment interface to $5 \mathrm{~cm}$, each $1 \mathrm{~cm}$ from 5 to $10 \mathrm{~cm}$, and each $2 \mathrm{~cm}$ below). Sub-samples were frozen $\left(-18^{\circ} \mathrm{C}\right)$, freeze-dried and stored under cold $\left(4^{\circ} \mathrm{C}\right)$ and dark conditions awaiting analysis.

Settling particles were collected using automated sediment traps moored $20 \mathrm{~m}$. a.b. (1830m and $2380 \mathrm{~m}$ at VA and VD, respectively) at VA and VD from 11/12/2005 to 10/10/2007. The cone-shaped traps (PPS-5, Technicap $\AA$ ) have a sampling aperture of $1 \mathrm{~m}^{2}$, covered with a honeycomb baffle of $1 \mathrm{~cm}$ diameter and with $10 \mathrm{~cm}$ deep cells at the top. Twenty-four collection bottles were set to a sampling interval of 9 days. The sampling bottles of all sediment traps were filled with filtered seawater and sodium borate buffered formalin to give a final concentration of 3\%. After recovery, each sediment trap sample was examined under a dissecting microscope to sort and count all organisms, and to remove swimmers. The remaining particles were rinsed with deionized water (Milli-Q $\left.{ }^{B}\right)$, freeze-dried and weighed. Organic carbon $\left(\mathrm{C}_{\text {org }}\right)$ and nitrogen $(\mathrm{N})$ concentrations were measured with a WR12 ${ }(\mathrm{LECO})$ elemental analyzer after removing carbonates with a $2 \mathrm{~N} \mathrm{HCl}$ solution. Details are given elsewhere (Khripounoff et al., 2009).

Mercury analyses were carried out on a semi-automatic AMA-254® (ALTEC) analyzer. Aliquots of sediments were introduced into the system, exposed to a high temperature $\left(550^{\circ} \mathrm{C}\right)$, so that $\mathrm{Hg}$ was volatilized and concentrated by amalgamation on a gold trap before being thermally dissociated and vaporized, and measured by atomic absorption spectrometry (Cossa et al., 2002). The method detection limit was $0.007 \mathrm{\mu g} \mathrm{g}^{-1}$ calculated as 3.29 times the standard deviation of the blank. The reproducibility was $1.8 \%$ for material of which $\mathrm{Hg}$ concentration was $0.092 \mu \mathrm{g} \mathrm{g}^{-1}$. Certified reference material (CRM) MESS-2 was used to assure the quality control of the method, and the values obtained $\left(0.092 \pm 0.002 \mu \mathrm{g} \mathrm{g}^{-1}\right.$ ) were always within the range of the certified values $0.092 \pm 0.009 \mu \mathrm{g} \mathrm{g}^{-1}$ (Table S1).

Iron and Al concentrations were determined by atomic absorption spectrophotometry (AAS, Varian, SpectrAA 600®). Other TM ( $\mathrm{Li}, \mathrm{V}, \mathrm{Cr}, \mathrm{Mn}, \mathrm{Ni}, \mathrm{Cu}, \mathrm{Zn}, \mathrm{Ag}, \mathrm{Cd}$ and $\mathrm{Pb}$, including its stable isotopes) and major elements $(\mathrm{Mg}, \mathrm{Si}, \mathrm{Ca})$ analyses were performed after total dissolution of the sediment with a mixture of $\mathrm{HCl}, \mathrm{HNO}_{3}$, and $\mathrm{HF}$ in hermetically sealed Teflon bombs according to the protocol described by Loring and Rantala (1990) and modified by Chiffoleau et al. (2004). All reagents used were SupraPur ${ }^{\circledR}$, obtained from Merck. Concentrations were determined using inductively coupled plasma mass spectrometry (ICP-MS, Thermo Electron Corporation, Element X Series $\left.{ }^{\circledR}\right)$. The determinations were validated using CRMs MESS-3 and BCSS-1. A blank sample and CRM were included with each 
batch of 15 samples in the total digestion procedure and then analyzed with ICP-MS and AAS. The blank values were always below the detection limits. Values obtained for major element analysis were always within the range of certified values (Table S1).

Radioelement analyses (234Th, 210Pb, 226Ra, 137Cs) were performed on 8-12g dried sediment using a semi-planar germanium detector (EGSP 2200-25-R, EURYSIS Measures) (Schmidt et al., 2009). Calibration of the $Y$ detector was achieved using certified reference material (IAEA: RGU, IAEA314), activities are expressed in mBq.g-1 and errors are based on 1 SD counting statistics. Excess 234Th and $210 \mathrm{~Pb}$ data were calculated by subtracting the activity supported by their parent isotope, $238 \mathrm{U}$ and 226Ra respectively, from the total activity in the sediment, and then by correcting 234Th values for radioactive decay that occurred between sample collection and counting (this correction is not necessary for 210Pb because of its longer half-life). Errors on 234Thxs and 210Pbxs are calculated by propagation of errors in the corresponding pair, 234Th and 238U, or 210Pb and 226Ra. Taking into account its very short half-life and the mean oceanic sedimentation rates (usually $<10 \mathrm{~mm} \mathrm{yr}-1$ ), 234Thxs should be present only at the water-sediment interface. Its penetration to variable depths indicates efficient mixing of the upper sediments, usually by bioturbation (Schmidt et al, 2002). The sedimentation rates can be calculated from 210Pbxs profiles using the constant flux-constant sedimentation (CFCS) model (Robbins, 1978):

$$
\left[{ }^{210} \mathrm{~Pb}_{\mathrm{xs}}\right]_{\mathrm{z}}=\left[{ }^{210} \mathrm{~Pb}_{\mathrm{xs}}\right]_{0} \mathrm{e}^{-\lambda(\mathrm{z} / \mathrm{s})}
$$

where $\left[{ }^{210} \mathrm{~Pb}_{\mathrm{xs}}\right]_{0, z}$ are the activities of excess ${ }^{210} \mathrm{~Pb}$ at surface, or the base of the mixed layer, and depth $\mathrm{z}, \lambda$ the decay constant of ${ }^{210} \mathrm{~Pb}\left(0.0311 \mathrm{yr}^{-1}\right)$, and $\mathrm{S}$ the sedimentation rate.

\subsection{Statistical Analysis and Normalization}

We applied Principle Components Analysis (PCA), a multivariate technique, to reduce the in which the numbers of variables are reduced to a smaller number of factors that describe the principal variability or joint behavior of the data set. Geometrically, this new set of variables represents a principal axis rotation of the original coordinate axes of the variables around their mean (Jackson, 1991; Huang et al., 2010). The statistical computations were performed with XLSTAT® software from Addinsoft.

In order to test if the observed variations in the profiles were the result of mineral changes within the cores, the $\mathrm{Ag}, \mathrm{Cd}$ and $\mathrm{Hg}$ concentrations were geochemically normalized by the use of tracer elements (Kersten and Smedes, 2002). Aluminum and Li were chosen as granulometric normalizer elements to take into account the clay fraction with its high specific surface, which favors metal binding (Loring, 1990).

\section{Results}

The results of chemical analyses, including isotopic measurements are given in tables 1, 2, 3 and 4 for particles from sediment traps, VA and VD sediment cores respectively.

\subsection{Major elements, organic matter and $\mathrm{Mn}$ in marine sediments}

In both sediment cores Si distribution mirrored the Ca distribution (Fig. S1). Silicated material dominated the carbonated material in core VD (except at the surface), while it was the inverse in the VA core (Figs. S1a and b). Aluminium and Fe vertical distributions were parallel and less variable ranging between 4 and 5\%, and between 2 and 3\%, respectively (Figs. S1c and d). A sub-surface Ca peak is located between 1.25 and $3.25 \mathrm{~cm}$ below the surface in core VA (Fig. S1a). Below, between 2.75 and $4.25 \mathrm{~cm}$, a Si enrichment (Figs. S1a and b), associated with relatively low Al content (Figs. S1c and d), was observed in both sediment cores. The Si/Al and Mg/Ca ratios in the 2.75 to $4.25 \mathrm{~cm}$ strata suggest the presence of a sandy deposit layer dominated by silicated and carbonated materials at the bottom and top of the layer, respectively (Figs. 2a and b).

Organic carbon varied from 0.43 to 0.66 and 0.32 to $0.54 \%$ at VA and VD respectively; these typical values for offshore Mediterranean sediment (Buscail et al., 1990) indicate highly mineralized organic matter (OM). The VA profile does not show any systematic trend, whereas the VD profile showed 
higher values at the upper $\mathrm{cm}$ of the core followed by a rapid decrease (Fig. 2c). Sandy layers are generally poor in OM compared to fine-grained sediments.

Manganese profiles (Fig. 2d) exhibited in both sediment cores typical sub-surface maximum peaking at 0.75 and $2.25 \mathrm{~cm}$ at VA and VD respectively; this indicates that the redox front was deeper at the VD site than in VA. In addition, since sulfate reduction within the $20 \mathrm{~cm}$ core at DYFAMED is unlikely (Fernex et al., 1992), the redox condition in the VD core between $2.5 \mathrm{~cm}$ and the bottom can be qualified as sub-oxic. In trapped particles from VD the high $\mathrm{Mn}$ content suggests oxidized material (Table 1).

\subsection{Trace metals in marine sediments and trapped particles}

Core VD presents the highest $\mathrm{Hg}, \mathrm{Cd}$ and $\mathrm{Ag}$ enrichments in the upper centimeters with a slight continuous decreasing trend towards the bottom (Fig. 3b), whereas in core VA, Hg shows the same enrichment values in the upper centimeters and only little down-core variability (Fig. 3a). Cadmium and Ag present similar type of variability, but do not show any specific down-core trend. The occurrence of the sandy layer can be discerned from the Cd profile, which mirrors the Si/Al profile (Fig. 2a).

The vertical variation of TMs within the cores is similar with or without the normalization procedures (Figs. 3c-f). The only noticeable changes are in the VD core, where $\mathrm{Ag} / \mathrm{Li}$ and $\mathrm{Cd} / \mathrm{Li}$ profiles (Fig. 3d) show more convincing evidence of increasing values from the bottom to the top of the core compared to the $\mathrm{Ag}$ and $\mathrm{Cd}$ profiles (Fig. 3b). The normalized $\mathrm{Ag}, \mathrm{Cd}$ and $\mathrm{Hg}$ distributions in core VD (Figs. $3 \mathrm{~d}$ and f) permit the smoothing of the profiles, and reveal that the TM surface enrichments follow the following order: $\mathrm{Hg}>\mathrm{Cd}>\mathrm{Ag}$. (Fig. $3 \mathrm{~d}$ ). At VA, the normalization resulted in complex distributions, with a maximum occurring at the surface for $\mathrm{Hg}$ and between 6 and $10 \mathrm{~cm}$ for $\mathrm{Ag}$ and $\mathrm{Cd}$ (Figs. 3c and e). While at $\mathrm{VA}, \mathrm{Cr}, \mathrm{Ni}, \mathrm{Cu}, \mathrm{Zn}$ and $\mathrm{Pb}$ exhibited surface enriched distributions, at $\mathrm{VD}$ only $\mathrm{Pb}$, and, to a lesser extent $\mathrm{Cu}$ and $\mathrm{Zn}$, testified of a surface enrichment (Tables 2 and 3, Fig. S2). Those results are consistent with the observations of Martin et al. (2009) at the DYFAMED site. Trapped particles were enriched in TMs and OM compared to the underlying sediments (Tables 1-3).

\subsection{Stable $\mathbf{P b}$ isotopes}

In both cores, $\mathrm{Pb}$ isotopic ratio distributions (Figs. 2e and $\mathrm{f}$, Table 4) showed lowest values at the surface: 1.180 and 1.184 for the ${ }^{206 / 207} \mathrm{~Pb}$ ratio, and 0.479 and 0.480 for the ${ }^{206 / 208} \mathrm{~Pb}$ at VA and VD, respectively. Within the VA core, the shape of the vertical ${ }^{206 / 207} \mathrm{~Pb}$ ratio profile exhibits a maximum between 2 and 4cm (Fig. 2e) associated to the sandy layer with bigger grain size (Mas et al., 2010). For VD the possible increase due to the presence of the sandy layer is engulfed within a regular increase from 1.194 to 1.202 downward (Fig. 2e). This pattern confirms the findings of Martin et al. (2009) at the DYFAMED site. Higher ${ }^{206 / 208} \mathrm{~Pb}$ ratios (0.484; Fig. 2f) occurred at $7.5 \mathrm{~cm}$ (and at $13 \mathrm{~cm}$ to a lesser extent) down in the VA core, coincidental with minimal $\mathrm{Cr}, \mathrm{Ni}, \mathrm{Zn}$ and $\mathrm{Pb}$ concentrations (Fig. S2a).

Particles from sediment traps exhibited a large range of ${ }^{206 / 207} \mathrm{~Pb}$ ratios (1.172-1.190). Conversely, lowest ${ }^{206 / 208} \mathrm{~Pb}$ ratios were associated to highest $\mathrm{Cr}, \mathrm{Ni}, \mathrm{Cu}, \mathrm{Zn}, \mathrm{Hg}, \mathrm{Pb}$ and $\mathrm{C}_{\text {org }}$ concentrations (Tables 1 and 4).

\section{Discussion}

The aim of this paper is to determine the magnitude and chronology of the anthropogenic impregnation by $\mathrm{Hg}$, and other TMs of environmental concern $(\mathrm{Cr}, \mathrm{Ni}, \mathrm{Cu}, \mathrm{Zn}, \mathrm{Ag}, \mathrm{Cd}$ and $\mathrm{Pb}$ ) in the sediments accumulated at the DYFAMED station. Although, this scheme has been partially confirmed by Martin et al. (2009) for $\mathrm{Cu}$ and $\mathrm{Pb}$ in a similar study, the same authors suggest that the lateral advection of sediment from the adjacent Var Canyon by gravity flow accounts for a fraction of TMs accumulated in DYFAMED sediments. Based on a sediment trap deployment during 2005-2007, Khripounoff et al. (2009) concluded that the Var River flood did not reach the DYFAMED site. Although, this does not preclude that this type of event may exceptionally occur.

\subsection{Sedimentary context and geochronology}

The VA core, collected in the Var Canyon, comes from a terrace, where recent sedimentary processes are dominantly depositional (Mas et al., 2010). The high ${ }^{210} \mathrm{~Pb}_{\mathrm{xs}}$ and ${ }^{234} \mathrm{Th}$ activities of the uppermost sediments attest to a layer of recently deposited material. Relatively low ${ }^{206 / 207} \mathrm{~Pb}$ ratio values in the surface layer (Table 4), suggest anthropogenic $\mathrm{Pb}$ inputs. Two other sequences are found below: from 0.8 to $2.1 \mathrm{~cm}$, a graded sequence is observed and has been interpreted as a deposit of a 
slope-failure turbidity surge. From 2.1 to $5.1 \mathrm{~cm}$, a sequence deposited by a river-flood induced turbidity current (Mas et al., 2010), with a succession of various proportions of Al, Si and Ca (Figs. S1a and c) and higher ${ }^{206 / 207} \mathrm{~Pb}$ ratios is observed (Fig. 2e). Turbiditic deposits are also suggested by the higher values of the ${ }^{206 / 208} \mathrm{~Pb}$ ratios at $7.5,13$ and $19 \mathrm{~cm}$ (Fig. $2 \mathrm{f}$, Table 4). Those ${ }^{206 / 207} \mathrm{~Pb}$ ratios indicate the presence of significant anthropogenic $\mathrm{Pb}$ inputs (Komareck et al., 2008). The ${ }^{210} \mathrm{~Pb}_{\mathrm{xs}}$ profile of the VA core is not appropriate to derive sedimentation rates due to the occurrence of multiple turbidite deposits. Although, by considering only the top and bottom activities (Fig. S3a), it is possible to derive a maximum apparent sedimentation rate of about $10 \mathrm{~mm} \mathrm{yr}^{-1}$, of the same order as the value obtained from the distribution of ${ }^{210} \mathrm{~Pb}_{\mathrm{xs}}$ in a $80 \mathrm{~cm}$ long core taken from the same terrace (Mas et al., 2010). The high activity of ${ }^{137} \mathrm{Cs}$ in depth corroborates our estimate from the ${ }^{210} \mathrm{~Pb}_{\mathrm{xs}}$ data. These results strongly suggest that the sediments at the bottom of the VA core $(32 \mathrm{~cm})$ have been deposited within the last 50 years in a complex manner as a result of multiple turbiditic events mixing old and more recent (and anthropized) sediments.

At the DYFAMED site (VD), ${ }^{210} \mathrm{~Pb}_{\mathrm{xs}}$ activity is highest at the top core and, followed by an exponential decay that is suitable for calculating a sedimentation rate by using the CFCS model (Fig. S3a). The estimate of $0.4 \mathrm{~mm} \mathrm{yr}^{-1}$ is coherent with values calculated in a nearby core (Martin et al., 2009). Consistently, ${ }^{137} \mathrm{Cs}$ profile exhibited high activities within the two upper centimeters to become negligible below $3 \mathrm{~cm}$, indicating sediment being deposited before 1950 (Fig. S3b).

Martin et al (2009) have validated their estimation by exploring the presence of sandy layers throughout the core, searching for chronostratigraphic references. These converging clues suggest that the sediment at the bottom of the VD core $(17 \mathrm{~cm})$ was deposited circa 400 years ago. Moreover, the values of the ${ }^{206 / 207} \mathrm{~Pb}$ ratios, which approach the value of natural $\mathrm{Pb}$ (Komarek et al., 2008) from $4 \mathrm{~cm}$ to the bottom of the core (Fig. 2e, Table 4). Considering all those evidences, we are confident with the age estimate for this core.

The large difference in the sedimentation rates of the sediment deposited in the two cores $(>10$ compared to $0.4 \mathrm{~mm} \mathrm{yr}^{-1}$ at VA and VD, respectively), suggests that, in spite of the similarity of their vertical position in the cores (between 2 and $4 \mathrm{~cm}$ in both cores), the two identified sandy layers do not refer to the same event. The major event at VA would be recent, while the turbidite at VD would have occurred one century ago. According to Khripounoff et al. (2009), high frequency sediment gravity flow events have occurred in the Var Canyon system during our sampling period (six events in two years). These events at VA occurred during Var River floods due to rainstorms, rainfall and snow melt. On the contrary, at the DYFAMED site, the particle flux, calculated from the sediment trap data, has increased only on one occasion (February 2006), but independently of the Var River flood, as a result of resuspension of the sediment triggered by the intensification of the "Ligurian/Northern current" (Khripounoff et al., 2009) and a winter convection that reached $>2000 \mathrm{~m}$-depth (Marty and Chiavérini, 2010). The occurrence of a 100-year old turbidite, with variable thickness, present at the DYFAMED site (Gehlen et al., 1997) is a result of the 1887 earthquake that occurred in the Ligurian region Martin et al. (2009). The distinct temporal scales of sedimentary events at VA and VD are thus evidenced. In addition, the distinct sources of material deposited at VA and VD are supported by stable $\mathrm{Pb}$ isotope ratios of materials collected in sediment traps (Table 4). The anthropogenic fraction of $\mathrm{Pb}$ in material collected in the sediment traps is higher (low ${ }^{206 / 207} \mathrm{~Pb}$ ratios) at DYFAMED, which is located at the eastern part of the sedimentary ridge (VD), than in the Var Canyon (VA). This may be related to the relative abundance of atmospherically transported contaminated material, compared to those of riverine sources.

\subsection{Turbidites effect on TM distributions}

We have taken into consideration the mineralogical and granulometric aspects by identifying the main changes of major elements (Si/Al and $\mathrm{Mg} / \mathrm{Ca}$, Figs. $2 \mathrm{a}$ and $\mathrm{b}$ ). These ratios give indications about the nature of the sediment: sand, carbonate or clay. Normalization to Li and Al (Figs. 3c-f and S4) allowed us to correct the grain size effect on TM concentrations (Loring, 1990). Major marked discontinuities within both VA and VD cores appear between 2 and 4cm (Figs. S1 a and b), which are associated with high Si/Al (Fig. 2a) and low $\mathrm{C}_{\text {org }}$ (Fig. 2c). At 11 and $17 \mathrm{~cm}$ in VD, similar features can be seen, although with a smaller amplitude. These chemical characteristics, notably the high Si/Al ratios (>3.8), are consistent with the presence of a sandy layer carried there as a turbidite. As previously discussed (4.1.), the sequences identified in the VA core result from turbidity currents generated by slope-failures or by the Var River floods, while in the VD core it is more likely an advection material from a large-scale turbidity current triggered by an earthquake that occurred at the end of the XIX ${ }^{\text {th }}$ century. 
The main sequences, identified in the VA core, have been documented by Mas (2009) and summarized by Mas et al. (2010). They consist of the superposition of three layers: the first one, named "s1" in Mas et al. (2010), from 0 to $0.8 \mathrm{~cm}$ is a red layer of terrigenous matter; the second one, named "s2", from 0.8 to $2.1 \mathrm{~cm}$ is a green-brown silt-clay layer (mainly quartz and carbonate) and the third one, named "s3", from 2.1 to $5.1 \mathrm{~cm}$ is a yellow-brown layer of increasing then decreasing grain size, named "hyperpycnite" by Mulder et al. (2001). This assemblage of three sequences is well characterized by the $\mathrm{Ca}$ and $\mathrm{Si}$ changes between 0.75 and 1.25 , between 1.75 and 2.75 and at $4.25 \mathrm{~cm}$ (Fig. S1). The VA "s2" and "s3" events result in lower Hg concentration in the layer located between 1.5 and $3.5 \mathrm{~cm}$ (Fig. 3a), whereas $\mathrm{Hg}$ concentrations increase below 4cm-depth, testifying that the sediments on which the "s2" and "s3" have deposited were already anthropized. The fact that comparable vertical variations were observed for total $\mathrm{Hg}$ concentrations and normalized values might reflect different sources of the deposited material. Similar effects are more marked for certain other TMs (Figs. S2 and S4). The turbidite effect is striking for $\mathrm{V}$ and $\mathrm{Cr}$ and also apparent to a lesser extent for $\mathrm{Cu}, \mathrm{Zn}$ and $\mathrm{Pb}$. These differences among TMs derive from the amplitude of the difference between the TM concentrations of the "s2" and "s3" turbidites and those of the adjacent sediment in the core, leading to apparent increase or decrease in the turbiditic layers. These changes are related to the origin of the sediment: turbidity current generated by slope failure and hyperpycnal current may have distinct compositions with distinct anthropization degree related to their source and "geochemical history". After normalizations to Li, the lowering of TM concentrations induced by the VA turbidites is still detectable, with lower ratios for $\mathrm{V}, \mathrm{Cr}, \mathrm{Ni}, \mathrm{Cu}, \mathrm{Hg}$ and $\mathrm{Pb}$ (Figs. 3c and $\mathrm{S} 4 \mathrm{a}$ ); this suggests that the dilution by the turbidite is not only the consequence of grain size differences but probably also of differences in the anthropization level of the various layer of the core. Hyperpycnal currents, for example, directly generated by floods are a continuation of the river flood under submarine condition supplying continental material in part from the heterogenous Var River basin drainage, whereas turbiditic currents generated by slope failure may carry ancient and reworked deposits. For Ag and Cd the Li normalization smoothes the profiles (Fig. 3c), suggesting a lower anthropogenic impact of those two TMs. However, both are highly soluble and are desorbed by chlorocomplexation during sediment resuspension (Comans and van Dijk, 1988; Kramer et al., 2002). At VD the turbidites are poorly visible in the Ag, Cd, Hg, and Pb vertical profiles; whereas lower $\mathrm{V}$ and $\mathrm{Cr}$ concentrations were associated to the turbidite layers (Figs. 3d, S2b and S4b).

\subsection{TMs redistribution and mobilization during $O M$ transformation in sediments and the epibenthic layer}

In order to explore the nature of the $\mathrm{OM}$ in the sediment, we examined the $\mathrm{C}_{\text {org }}$ distribution (Fig. 2c) and the $\mathrm{N} / \mathrm{C}_{\text {org }}$ ratios (Fig. S5). It has been recently shown by Perdue and Koprivnjak (2007) that N/C org ratio is more suitable than $\mathrm{C}_{\text {org }} / \mathrm{N}$ to decipher sources of $\mathrm{OM}$ in sediments. In both sediment cores the $\mathrm{C}_{\text {org }}$ is slightly lower in the turbidite layers and enriched in the superficial layers. Overall $\mathrm{C}_{\text {org }}$ values are around 0.38 and $0.50 \%$ at VA and VD, respectively, testifying of largely oxidized OM as usually found in Mediterranean sediments (Buscail et al., 1990). On the other hand, N/C ratios at VA decrease slightly from the top to the bottom of the core from 0.11 to 0.08 , which could be attributed to early diagenetic processes that strip labile $\mathrm{N}$ first from the fresh sediment (Dauwe et al., 1999). At VD, the ratio remains rather stable with a mean value of $0.10 \pm 0.01$. These values are higher than those of VA, suggesting a larger influence of the marine phytoplankton in the VD deposits (with a Redfield ratio $\mathrm{C}_{106} / \mathrm{N}_{16}$, the $\mathrm{N} / \mathrm{C}$ ratio of fresh marine phytoplankton is around 0.16, Quigg et al., 2003). In brief, the surface sediment at VA and VD is mainly constituted of a thin slightly organically enriched layer, where the $\mathrm{OM}$ oxidation is quite active, underlying largely oxidized OM from primary production. These distributions are disrupted by turbiditic events, characterized by lower $\mathrm{C}_{\text {org }}$. Before exploring the anthropization of the studied sediments, the questions we want to address are: (i) does the OM degradation in the surface sediment mobilize TMs from the solid phase, and (ii) does this diagenetic process lead to a TM enrichment in the oxihydroxides present at the redoxcline? In the absence of "reactive Fe" (Fe not associated with crystal phase) data, the Mn peak position can be used to localize the redox front in sediment since it relates to the presence of oxihydroxides (e.g. Froelich et al., 1979; Haese, 2006). In VA and VD cores the Mn peaks appear not to be linked to the turbidite events (Fig. 2d). In core VA the peak is located above the turbidite and, in VD, within its top part. To explore the possible TMs enrichment within the oxihydroxides, which would bring evidence for TMs redistribution effect in the sediments; we looked at the TMs versus Mn relationships. At VD no significant relationship between TMs and Mn were found. At VA, we found significant $(p<0.01)$ relationships between $M n$ and $\mathrm{Hg}\left(\mathrm{R}^{2}=0.57\right), \mathrm{Cr}\left(\mathrm{R}^{2}=0.48\right), \mathrm{Ni}\left(\mathrm{R}^{2}=0.57\right)$, and $\mathrm{Pb}\left(\mathrm{R}^{2}=0.43\right)$. However, if we exclude the three highest $\mathrm{Mn}$ concentrations (interpreted as the $\mathrm{Mn}$ oxide peak) from calculations, it appears that the values of $\mathrm{R}^{2}$ 
increase to 0.76 and 0.83 for $\mathrm{Ni}$ and $\mathrm{Cr}$ respectively, and did not change for $\mathrm{Pb}\left(\mathrm{R}^{2}=0.44\right)$. This suggests that the correlation between these three TMs and Mn result most probably from mineralogy composition of the sediment. Thus, for all studied TMs, except $\mathrm{Hg}$, the redistribution of within the sedimentary column, due to a possible oxihydroxide enrichment, is negligible and cannot significantly perturb the TM profiles. The behavior of $\mathrm{Hg}$ at VA deserves a particular attention since the oxihydroxides, occurring within the $1.5 \mathrm{~cm}$-thick surface layer of sediment, are $\mathrm{Hg}$ enriched compared to sediment below (Fig. 3a). Similar situations have been found in other marine sediments, along the Siberian shelf (Cossa et al., 1996) and in the deep Arctic (Gobeil et al., 1999). In the first case it has been attributed to the very high amount of $\mathrm{Mn}$ involved in the redox cycling on the Siberian shelf and in the second to the very low sedimentation rate which favors the TM redistribution in the sediment. None of these explanations seem to concern the Var Canyon sediments. At this stage we cannot conclude about the reality of an implication of $\mathrm{Hg}$ in the Mn recycling process in VA sediment, but our observations prohibit any further chronological interpretation of the $\mathrm{Hg}$ profile in the Var Canyon.

The correlation coefficients between TMs and $C_{\text {org }}$ exhibits marked differences between the two cores (Fig. S6, Tables S2 an S3). For the VA core the statistically significant $(p<0.01)$ correlations with $\mathrm{OM}$ concern $\mathrm{V}, \mathrm{Cr}$ and $\mathrm{Cu}$, whereas for $\mathrm{VD}$ it concerns $\mathrm{Cu}, \mathrm{Zn}, \mathrm{Ag}, \mathrm{Cd}, \mathrm{Hg}$ and $\mathrm{Pb}$. This suggests that the material bearing TMs differs according to the sites. This hypothesis is supported by the results of a Principal Component Analysis (PCA) showing that terrigenous proxies (Al, $\mathrm{Li}, \mathrm{Fe}$ ) were more influencing the TMs distribution in the VA core compared to the VD core (Fig. S6). This is consistent with the idea of a dominant marine origin of sedimentary material at the pelagic site VD, whereas the continental influence is more important at the Var Canyon site VA. Interestingly however, $\mathrm{N}$ versus $\mathrm{Hg}$ and $\mathrm{Pb}$ relationship are significant at $\mathrm{VA}$ (Fig. S6) suggesting that, even in the canyon, the marine OM serves as a sedimentation vector for atmospheric borne $\mathrm{TM}$, such as $\mathrm{Hg}$ and $\mathrm{Pb}$.

Several studies pointed out the significant correlation between concentrations of $\mathrm{Hg}$ and $\mathrm{OM}$ in marine sediments (e.g. Hammerschmidt and Fitzgerald, 2004; Hollweg et al., 2009; Hare et al., 2010), showing that particulate $\mathrm{C}_{\text {org }}$ is the main vector for this TM to sediments. Therefore, at a constant $\mathrm{Hg}$ deposition onto sea-surface, the variation in the intensity of the biological production in the marine euphotic layer will generate variation in the $\mathrm{Hg}$ concentrations in the particulate matter settling down to the sea floor. Conversely, at constant primary production, the $\mathrm{Hg}$ concentration variations in the downward particulate matter flux would reflect the variation of the $\mathrm{Hg}$ atmospheric deposition. Alternatively, OM degradation in the sediment may cause changes in its complexation and/or sorption capacity toward $\mathrm{Hg}$ (because of the possible changes in the nature and abundance of ligands) causing changes in the $\mathrm{Hg} / \mathrm{C}_{\text {org }}$ ratio. This latter hypothesis is not supported in the VD core, since the $\mathrm{N} / \mathrm{C}_{\text {org }}$ ratio did not show large changes within the core (Fig. S5).

At the DYFAMED site, removing the turbiditic layer data, the correlation of $\mathrm{Hg}$ with $\mathrm{C}_{\text {org }}$ is highly significant $(p<0.01)$ with $R^{2}=0.94\left(R^{2}=0.81\right.$ including the data from the turbidite samples). The $\mathrm{Hg} / \mathrm{C}_{\text {org }}$ profile exhibits an exponential increase from the bottom to the top of the core (Fig. 4). This led us to suggest that a fraction of the $\mathrm{Hg}$ present in the freshly deposited sediment is mobilized from particulate OM during its mineralization. This process seems to reflect what we observed occurring in the sediment trap material in the epibenthic environment.

The material in the VD sediment trap, moored 20m.a.b., was enriched in TMs and organic carbon (Fig. S7b, Table 1) compared to deposited sediments; this confirms that the TM vector to the sediment is the biogenic particles and attests of a TM mobilization is occurring during the OM degradation in the epibenthic zone. A common anthropogenic (atmospheric) origin of $\mathrm{Hg}$ and $\mathrm{Pb}$ is more than likely according to the relationships found between $\mathrm{Hg}$ concentration and ${ }^{206 / 207} \mathrm{~Pb}$ ratio (Fig. S7a). Other anthropogenic TMs are also enriched, but to a lesser extent, i.e. $\mathrm{Cr}, \mathrm{Ni}, \mathrm{Zn}$ and $\mathrm{Ag}$. Based on sediment trap data, the mass fluxes averaged 4.23 and $0.46 \mathrm{~g} \mathrm{~m}^{-2} \mathrm{~d}^{-1}$ at VA and VD, respectively (Mas, 2009). The fluxes of the associated TM and their concentrations are given in table 5 . The obtained values for $\mathrm{Hg}$ flux at the DYFAMED site of $0.083 \mu \mathrm{g} \mathrm{m}^{-2} \mathrm{~d}^{-1}$ in sediment traps and $0.023 \mu \mathrm{g} \mathrm{m}^{-2} \mathrm{~d}^{-1}$ in sediments are comparable to values $\left(0.033-0.145 \mu \mathrm{g} \mathrm{m}^{-2} \mathrm{~d}^{-1}\right.$ ) recently published for the Hudson Bay (Hare et al., 2010). We used the flux derived from sediment and sediment traps to calculate the TM remobilization from the sediment. According to these values, the TMs remobilized from surface sediment vary from $55 \%$ for $\mathrm{Zn}$ to $73 \%$ for $\mathrm{Hg}$ and $\mathrm{Cu}$, except for $\mathrm{Cd}$ for which it is only $37 \%$. This latter value probably reflects the faster release of $\mathrm{Cd}$ from settling particles in the water column (Fisher, 1985); Cd mobilization probably occurs in the water column above the epibenthic layer. A similar calculation has already been performed for $\mathrm{Hg}$ by Cossa and Coquery (2005), in order to compare $\mathrm{Hg}$ concentration in sediment trap particles and surface sediments. They noted a large difference in the $\mathrm{Hg}$ concentration of settling particles collected in the sediment trap in the abyssal plain of the Algero-provençal sub-basin (between Sardinia and Balearic islands) and the deposited sediment, 50m beneath. Decreasing $\mathrm{Hg}$ 
concentrations (from $0.10-0.16$ to $0.08-0.09 \mu \mathrm{g} \mathrm{g}^{-1}$ ) were parallel to the $\mathrm{C}_{\text {org }}$ content of the material, which decreased from $3-9$ to $0.6 \%$. The authors concluded that $\mathrm{Hg}$ was mobilized in the vicinity of the sediment. The present data confirm their findings; $\mathrm{Hg}$ and other TMs are enriched in the particulate matter collected in the sediment traps compared to the underlying surface sediment (Tables 1 to 4). The mobilization of TMs during the early diagenisis of the OM in the fluffy layer of the epibenthic zone is significant.

\subsection{Historical variations of contaminant fluxes and sources at the DYFAMED site}

Based on ${ }^{206 / 207} \mathrm{~Pb}$ and ${ }^{206 / 208} \mathrm{~Pb}$ ratios in the material from the VD traps, the particles transported $20 \mathrm{~m}$.a.b. were highly anthropized $\left({ }^{206 / 207} \mathrm{~Pb}<1.180\right.$ and $\left.{ }^{206 / 208} \mathrm{~Pb}<0.480\right)$. They differed markedly from the material brought with the main identified turbidites, which were characterized by the abundance of pre-industrial material (Table 4). These evidences strongly suggest an anthropogenic origin for the material currently collected at the DYFAMED site; this material is mainly of atmospheric origin with a strong anthropogenic signature (Migon et al., 2008; Heimbürger et al., 2010). The VA core consists of a succession of turbidites, and the only feature we can conclude from ${ }^{210} \mathrm{~Pb}$ and ${ }^{137} \mathrm{Cs}$ data is that the material from the whole core is younger than 50 years. It is impossible to infer a real sedimentation rate from our data. For the VD core, after removing the turbidic event, we note an increase in the TM/Li signal from the bottom to the surface sediment (Figs. 3d and S4b). The amplitude of the increase is maximum for $\mathrm{Hg}-\mathrm{Zn}$, and decreases in the order $\mathrm{Hg}-\mathrm{Zn}>\mathrm{Pb}-\mathrm{V}>\mathrm{Cr}-\mathrm{Cu}-\mathrm{Ni}$. According to the ${ }^{210} \mathrm{~Pb}_{\mathrm{xs}}{ }^{-}$ derived sedimentation rate of $0.4 \mathrm{~mm} \mathrm{yr}^{-1}$ (Fig. S3a) at this site the Hg-enriched layer (the upper $2 \mathrm{~cm}$ ) of the sediment core corresponds to the sediment accumulation over the last 50 years, which is the period of the highest increase of $\mathrm{Hg}$ deposition on a global scale (Mason et al., 1994). It has been shown elsewhere that $\mathrm{Hg}$ emissions after a slow increase at the beginning of the $\mathrm{XX}^{\text {th }}$ century, accelerated after the Second World War and peaked at the end of the sixties (Hylander and Meili, 2003). The Hg distribution, in the sediment layers at the DYFAMED site, is consistent with this chronological scenario. The beginning of the increase occurred indeed 50 to 100 years ago. However there is no point in showing the beginning of the expected deposition decrease, but only a reduction in the rate of increase within the upper $0.5 \mathrm{~cm}$ (Fig. 4). The occurrence of smoothed TM profiles (including Hg, Figs. $3 \mathrm{~d}$ and $\mathrm{f}$, S4b and d) may not reflect real time variations of the inputs, as they may partially be the result of postdepositional processes including local mixing and bioturbation.

Elevated $\mathrm{Hg}$ concentrations in trapped particles and in the uppermost sediment layers from VD suggest recent inputs of anthropogenically-impacted material. If we hypothesize even partial but common atmospheric origin of $\mathrm{Pb}$ and $\mathrm{Hg}$ as a result of burning fossil fuel, especially coal (Fig. S7), ${ }^{206 / 207} \mathrm{~Pb}$ and ${ }^{206 / 208} \mathrm{~Pb}$ ratio values on the top of the cores should represent the thickness of the manimpacted sediment cores by these two air-borne elements. On the VD core the surface slice $(0-1 \mathrm{~cm})$ ${ }^{206 / 207} \mathrm{~Pb}$ and ${ }^{208 / 206} \mathrm{~Pb}$ reach values as low as 1.180 and 2.08 , reflecting, as shown in figure 5 , the signature of European coal and/or a mixture of anthropogenic $\mathrm{Pb}$ from coal and gasoline additives, with geogenic $\mathrm{Pb}$ (Komarek et al., 2008). A similar anthropogenic signal is also visible down to $1 \mathrm{~cm}$ of the VD core and in particles from the VD sediment trap. Below 2cm-depth in the VD core, the regular increase in the ${ }^{206 / 207} \mathrm{~Pb}$ strongly suggests a slight mixing of the surface sediment after deposition, in agreement with evidence of low bioturbation as recorded by seabed ${ }^{210} \mathrm{~Pb}_{\mathrm{xs}}$ and ${ }^{234} \mathrm{Th}_{\mathrm{xs}}$. While the ratios in the VD core reach natural value $\left({ }^{206 / 207} \mathrm{~Pb}=1.202 ;{ }^{206 / 208} \mathrm{~Pb}=0.485\right)$ at the base of the core, which correspond to pre-industrial period. The $\mathrm{Pb}$ isotopic ratios in the entire VA core reflect anthropized sediments $\left({ }^{206 / 207} \mathrm{~Pb}=1.181-1.187 ;{ }^{206 / 208} \mathrm{~Pb}=0.480-0.483\right)$, which is consistent with our age estimation for the bottom of VA core.

Thus, in summary, if we reasonably hypothesize (i) insignificant effects of turbiditic events (except the 1887 earthquake), (ii) negligible $\mathrm{Hg}$ mobility due to dissolution-precipitation of oxides during the redox change in the sedimentary column, and (iii) a stable $\mathrm{Hg} / \mathrm{C}_{\text {org }}$ ratio when $\mathrm{OM}$ ages (which is supported by the absence of relationship between $\mathrm{Hg}$ and $\mathrm{N} / \mathrm{C}_{\text {org }}$ ratio), thus the $\mathrm{Hg} / \mathrm{C}_{\text {org }}$ ratio change between the surface and bottom (excluding the turbidite layer) can be used to estimate the anthropogenic contribution (Fig. 4). Indeed a hypothesis of a constant $\mathrm{C}_{\text {org }}$ flux during the last 200 years from surface water to the sediment at the DYFAMED site is unlikely since the export of particulate organic matter occurs in pulses due to episodic water convection events (Martin et al., 2010). We observe an exponential trend in the $\mathrm{Hg}$ enrichment that started 250 years ago $(11 \mathrm{~cm}$-depth), and accelerated between 50 and 100 years ago (2 to $4 \mathrm{~cm}$-depth). The $\mathrm{Hg}$ enrichment factor, from preindustrial time to the present, estimated from the $\mathrm{Hg} / \mathrm{C}_{\text {org }}$ ratios (Fig. 4), is calculated to be around $60 \%$. This estimation is consistent with the global model proposed by Lamborg et al. (2002), which concluded that the atmospheric $\mathrm{Hg}$ reservoir has experienced a 3-fold increase since pre-industrial 
times, whereas the surface ocean and thermocline have only increased by a factor of 1.9 and 1.2 , respectively. However, before we can firmly conclude about the merit of $\mathrm{Hg} / \mathrm{C}_{\text {org }}$ ratio as a proxy for $\mathrm{Hg}$ deposition changes, further work on $\mathrm{Hg}$ early diagenesis is needed.

No other TM, but Cd (Fig. S8), exhibits a significant trend with depth. Conversely to $\mathrm{Hg}, \mathrm{Cd} / \mathrm{C}_{\text {org }}$ ratio vertical distribution would suggest suggests a $30 \%$ decrease of its deposition in the last decades, if the $\mathrm{Cd} / \mathrm{C}_{\text {org }}$ was conservative in the sediment. Although this result is consistent with the recent results of Heimbürger et al. (2010) who showed that Cd concentrations in marine aerosols sampled along the French Riviera (Cap Ferrat, near Nice) decreased by a factor larger than 2 within the last 15 years, the models of the Cd behavior in marine sediment (e.g., Gobeil et al., 1987) suggest that this kind of profile may more probably result for early diagenetic processes.

\section{Summary and Conclusions}

This paper documents the magnitude and the chronology of the anthropogenic impregnation by $\mathrm{Hg}$ and other TMs of environmental concern in marine sediment (core VD) accumulated at the DYFAMED site, in the Ligurian Sea (Northwestern Mediterranean). In order to check the possible lateral advection of material to this site, the characteristics of the sediments deposited at the Var Canyon (VA core) and the material collected with sediment traps moored at $20 \mathrm{~m}$.a.b. at the two sites was also examined. Major element distributions, coupled with the stratigraphic examination of the sediment cores allowed the nature and origin of the material accumulated to be characterized, including major turbiditic events. After discussion of the possible effects of lateral advection, redistribution of TMs among solid phases resulting from diagenetic processes, the $\mathrm{Hg}$ and stable $\mathrm{Pb}$ isotope distribution patterns pointed out the anthropogenic impregnation of the sediments at the DYFAMED site. We demonstrated conclusively that the DYFAMED site is suitable for addressing the temporal evolution of atmospherically-derived TMs in regional marine sediments. The Hg-enriched layer of the sediment represents the last 50 years, which is the period of the highest increase of $\mathrm{Hg}$ deposition at a global scale. With the hypothesis of the absence of significant post-depositional redistribution and a roughly constant $\mathrm{C}_{\text {org }}$ flux during the last 250 years from surface water to sediment, the $\mathrm{Hg} / \mathrm{C}_{\text {org }}$ enrichment between surface and pre-industrial levels is calculated at circa $60 \%$, consistent with the estimations of global $\mathrm{Hg}$ models. Conversely $\mathrm{Cd} / \mathrm{C}_{\text {org }}$ distribution would suggest a decrease in the $\mathrm{Cd}$ accumulation in the DYFAMED sediments during the last decades; however, for this very mobile TM, diagenetic processes probably govern the $\mathrm{Cd} / \mathrm{C}_{\text {org }}$ distribution (Gobeil et al., 1987). The environmental response to changes in atmospheric inputs, due to enhanced fossil fuel burning are clearly visible for $\mathrm{Hg}$ in marine sediment records. However, further research is needed to explore the merit of $\mathrm{Hg} / \mathrm{C}_{\text {org }}$ in marine sediment. Research should focus on its isotopic signature, which might have the potential to reveal further insights to its cycling, and in particular to trace changes in the hydrobiological setup (biological production, stratification, etc.) as well as changes of emission sources.

\section{Acknowledgements}

We gratefully acknowledge the skilful help of B. Averty and E. Rozuel for their analytical assistance. We thank Alan Hally for language corrections and Marion Stabholz for her insightful remarks. We would like to thank the reviewers for their very constructive and detailed comments wich greatly improved the manuscript. This research received funds from the PIM Medicis project and the PACA region, and was also partially supported by the EXTREMA project (ANR), the HERMES-HERMIONE projects, EC contract no GOCE-CT-2005-511234, funded by the European Commission Sixth Framework Program: thematic priority "Sustainable Development, Global Change and Ecosystems". This publication reflects only the views of the authors, and the EC is not liable for any use that may be made of the information contained herein.

\section{References}

Béthoux, J. P., L. Prieur and J.H. Bong, 1988. Le courant Ligure au large de Nice, Oceanologica Acta, $N^{\circ}$ SP, 59-67.

Boström, K. and D.E. Fisher, 1969. Distribution of mercury in East pacific sediments. Geochem. Cosmochim. Acta, 33: 743-745. 
Buscail, R., R. Pocklington, R. Daumas and L. Guidi, 1990. Fluxes and budget of organic matter in the benthic boundary layer over the northwestern Mediterranean margin. Cont. Shelf Res., 10: 10891122.

Canals, M., P. Puig, X.D. de Madron, S. Heussner, ,A. Palanques and J. Fabres, 2006. Flushing submarine canyons. Nature, 444 (7117): 354-357.

Chiffoleau, J.F., D. Auger, B. Boutier, E. Rozuel and I. Truquet, 2004. Dosage de certains métaux dans les sédiments et la matière en suspension par absorption atomique. Méthodes d'Analyses en milieu marin. Editions Ifremer, BP 70, F-29280 Plouzané, ISSN 1637-1844.

Comans R.N.J. and C.P.J. van Dijk, 1988. Role of complexation processes in cadmium mobilization during estuarine mixing. Nature 336 (6195): 151-154.

Cossa, D., M. Coquery, K. Nakhlé and D. Claisse, 2002. Dosage du mercure total et du monométhylmercure dans les organismes et les sédiments marins. Méthodes d'analyse en milieu marin. Co-édition Ifremer et Ministère de l'Ecologie et du Développement Durable. 26 pp. ISBN 284433-105-X.

Cossa, D. and M. Coquery, 2005. The Mediterranean mercury anomaly, a geochemical or a biological issue. Pp. 177-208. In: The Mediterranean Sea. Handbook of Environmental chemistry Vol. 5, Saliot, A. editor. Spinger, 413p. ISSN. 1433-6863.

Costa, A.M., M. Mil-Homens, S.M. Lebreiro, T.O. Richter, H. de Stigter, W. Boer, M.A. Trancoso, Z. Melo, F. Mouro, M. Mateus, J. Canário, V. Branco and M. Caetano, 2011. Origin and transport of trace metals deposited in the canyons off Lisboa and adjacent slopes (Portuguese Margin) in the last century. Mar. Geol., 282 (3-4): 169-177.

Dauwe, B., J.J. Middelburg, P.M.J Herman and C.H.R. Heip, , 1999. Linking diagenetic alteration of amino acids and bulk organic matter reactivity. Limnol. Oceanogr., 44 (7): 1809-1814.

Fernex, F. E., G. Février, J. Béna and A. Arnoux., 1992. Copper, lead, zinc trapping in Mediterranean deep-sea sediments: probable coprecipitation with Mn, Fe. Chem. Geol., 98: 293-306.

Fisher, N. S., 1985. Accumulation of Metals by Marine Picoplankton, Mar. Biol., 87: 137-142.

Fitzgerald, W.F., R.D. Engstrom, R.P. Mason and E.A. Nater, 1998. The case for Atmospheric Mercury Contamination in Remote Areas. Environ. Sci. Technol., 32: 1-7.

Froelich, P.N., G.P. Klinkhammer, M.L. Bender, N.A. Luedtke, G.R. Heath, D. Cullen, P. Dauphin, D. Hammond and B. Hartman, 1979. Early oxidation of organic matter in pelagic sediments of the eastern equatorial Altantic: suboxic diagenesis. Geochim. Cosmochim. Acta, 43: 1075-1090.

Gehlen, M., C. Rabouille, U. Ezat, and L. Guidi-Guilvard, 1997. Drastic changes in deep-sea sediment pore water composition induced by episodic input of organic matter. Limnol. Oceanogr., 42: 980-986.

Gehrke, G.E., J.D. Blum and P.A. Meyers, 2009. The geochemistry behavior and isotopic composition of $\mathrm{Hg}$ in the mid-Pleistocene western Mediterranean sapropel. Geochim. Cosmochim. Acta, 73: 1651-1665.

GESAMP (IMO/FAO/UNESCO/WHO/IAEA/UN/UNEP), 1990. Joint Group of Experts on the Scientific Aspect of Marine Pollution. The state of the Marine Environment; Rep. Stud. GESAMP № 39.

Gobeil, C., N. Silverberg, B. Sundby, D. Cossa, 1987. Cadmium diagenesis in Laurentian Trough sediments, Geochim. Cosmochim. Acta, 51 (3): 589-596.

Gobeil, C. and D. Cossa, 1993. Mercury in the sediments and sediment pore waters in the Laurentian trough. Can. J. Fish. Aquat. Sci., 50: 1794-1800.

Grousset, F. and O. Donnard, 1984. Enrichments in $\mathrm{Hg}, \mathrm{Cd}, \mathrm{As}$ and $\mathrm{Sb}$ in recent sediments of the Azores-iceland ridge. Geo-marine Letters, 4: 117-124.

Haese, R. R., 2006. The Biogeochemistry of Iron. p. 241-270. Chap 7 In: Marine Geochemistry, Schulz H. D. and M. Zabel eds. Springer, Berlin, 574pp.

Hare, A.A., G.A. Stern, Z.Z.A. Kuzyk, R.W. Macdonald, S.C. Johannessen and F. Wang, 2010. Natural and Anthropogenic Mercury Distribution in Marine Sediments from Hudson Bay, Canada. Environ. Sci. Technol.; 44 (15): 5805-5811. 
Hammerschmidt, C.R. and W.F., Fitzgerald, 2004. Geochemical controls on the production and distribution of methylmercury in near-shore marine sediments. Environ. Sci. Technol., 38: 1487-1495.

Heimbürger, L.E., C. Migon, A. Dufour, J.F. Chiffoleau and D. Cossa, 2010. Decadal trends and evolutions of trace-metals ( $\mathrm{Al}, \mathrm{Cd}, \mathrm{Co}, \mathrm{Cu}, \mathrm{Fe}, \mathrm{Mn}, \mathrm{Ni}, \mathrm{Pb}, \mathrm{Zn}$ ) in the western Mediterranean atmosphere, Sci. Total Environ., 408 (13): 2629-2638.

Hollweg, T.A., C.C. Gilmour and R.P. Mason, 2009. Methylmercury production in sediments of Chesapeake Bay and the mid-Atlantic continental margin. Mar. Chem., 114: 86-101.

Huang, J., H. Deokchoi, P. Hopke and T. Holsen, 2010. Ambient Mercury Sources in Rochester, NY: Results from Principle Components Analysis (PCA) of Mercury Monitoring Network Data Environ. Sci. Technol., 44: 8441-8445.

Hylander, L.D. and M. Meili, 2003. 500 years mercury production: global annual inventory by region until 2000 and associated emissions. Sci. Total Environ., 304: 13-27.

Jackson, J. E. 1991. A User's Guide to Principal Components; Wiley

Kramer J.R., B. Gaboury., K.C. Bowles, D.M. DiToro , R.T. Herrin, G.W. III Luther, H. Manolopoulos, K.A. Robillard., M.M. Shafer and J.R. Shaw, 2002. Environmental Chemistry of silver. In : Silver in the Environment: Transport, Fate and Effects. Andren A.W. \& Bober T.W., eds. SETAC Press. Brussels (Belgium).

Kersten, M. and F. Smedes, 2002. Normalization procedures for sediment contaminants in spatial and temporal trend monitoring. J. Environ. Monitoring, 4: 109-115.

Khripounoff, A., A. Vangriesheim, P. Crassous. and J. Etoubleau, 2009. High frequency of sediment gravity flow events in the Var submarine canyon (Mediterranean Sea). Mar. Geol., 263: 1-6.

Komarek, M., V. Ettler, V. Chrastny, V. and M. Mihaljevic, 2008. Lead isotopes in environmental sciences: A review. Environ. Int., 34: 562-577.

Lamborg, C., W.F. Fitzgerald, A. Damman, J. Benoit, P. Balcom and D. Engstrom, 2002. Modern and historic mercury fluxes in both hemispheres: global and regional mercury cycling implications. Global Biogeochemical Cycles, 16 (4): 1104.

Loring, D. H., 1990. Lithium- A new approach for the granulometric normalization of trace metal data. Mar. Chem., 29: 155-168.

Loring, D.H. and R.T.T. Rantala, 1990. Sediments and suspended particulate matter: total and partial methods of digestion. ICES Techniques in Marine Environmental Sciences, 9:14 p.

Martin, J., J.A. Sanchez-Cabeza, M. Eriksson, I. Levy and J. C. Miquel, 2009. Recent accumulation of trace metals in sediments at the DYFAMED site (Northwestern Mediterranean sea). Mar. Pollut. Bull. 59 (4-7): 146-153.

Martin, J., J.C. Miquel and A. Khripounoff. 2010. Impact of open sea deep convection on sediment remobilization in the western Mediterranean. Geophysical Research Letters, 37: L13604, doi:10.1029/2010GL043704.

Marty, J.C., 2002. The DYFAMED time series program (French JGOFS). Deep-Sea Res. II, 49: 1963-1964.

Marty, J.C. and J. Chiavérini, 2002. Seasonal and interannual variations in phytoplankton production at DYFAMED time-series station, northwestern Mediterranean Sea. Deep-Sea Res. II, 49: 2017-2030.

Marty, J.C., Chiavérini, J., 2010. Hydrological changes in the Ligurian Sea (NW Mediterranean, DYFAMED site) during 1995-2007 and biogeochemical consequences. Biogeosciences, 7: 2117-2128.

Mas, V., 2009. Caractérisation de l'activité hydrosédimentaire dans le Système Turbiditique du Var (NO Méditerranée) et de son enregistrement dans l'archive sédimentaire. PhD, University of Bordeaux 1 (204p); http://ori-oai.u-bordeaux1.fr/ori-oai-search/advanced-search.html.

Mas, V., T. Mulder, B. Dennielou, S. Schmidt, A. Khripounoff and B. Savoye. 2010. Multiscale spatio-tenporal variability of sedimentary deposits in the Var turbidite system (North-Western Mediterranean Sea). Mar. Geol., 275: 37-52. 
Mason, R.P., W.F. Fitzgerald and F.M.M. Morel, 1994. The biogeochemical cycle of elemental mercury: Anthropogenic influences. Geochim. Cosmochim. Acta, 58: 3191-3198.

Mercone, D., J. Thomson, I.W. Croudace and S.R. Troelstra., 1999. A coupled natural immobilisation mechanism for mercury and selenium in deep-sea sediment. Geochim. Cosmochim. Acta, 63: 1481-1488.

Migeon, S., T. Mulder, B. Savoye and F. Sage, 2006. The Var turbidite system (Ligurian Sea, northwestern Mediterranean)-morphology, sediment supply, construction of turbidite levee and sediment waves: implications for hydrocarbon reservoirs. Geo-Marine Letters, 26: 361-371.

Migon, C., V. Sandroni, J.C. Marty, B. Gasser and J.C. Miquel, 2002. Transfer of atmospheric matter through the euphotic layer in the northwestern Mediterranean: seasonal pattern and driving forces. Deep-Sea Res. II, 49: 2125-2141.

Migon, C., T. Robin, A. Dufour and B. Gentili, 2008. Decrease of lead concentrations in the Western Mediterranean atmosphere during the last 20 years. Atmos. Environ., 42: 815-821.

Miquel, J. C., S.W. Fowler, J. La Rosa and P. Buat-Menard, 1994. Dynamics of the downward flux of particles, carbon in the open northwestern Mediterranean Sea. Deep-Sea Res. I, 41: 243-261.

Muir, D.C.G., X. Wang, F. Yang, N.N, Guyen, T.A. Jackson, M. S. Evans, M. Douglas, G. Kock, S. Lamoureux, R. Pienitz, J. P. Smol, W. F. Vincent and A. Dastooro, 2009. Spatial Trends and Historical Deposition of Mercury in Eastern and Northern Canada Inferred from Lake Sediment Cores. Environ. Sci. Technol., 43: 4802-4809

Mulder, T., B. Savoye, J.P.M. Syvitski, and O. Parize, 1997. Des courants de turbidité hyperpycnaux dans la tête du canyon du Var? Données hydrologiques et observations de terrain. Oceanologica Acta, 20: 607-626.

Ogrinc, N., M. Monperrus, J. Kotnik, V. Fajon, K. Vidimova, D. Amouroux, D. Kocman, E. Tessier, S. Zizek and M. Horvat, 2007. Distribution of mercury and methylmercury in deep-sea surficial sediments if the Mediterranean Sea. Mar. Chem., 107: 31-48.

Palanques, A., P. Masque, P. Puig, J.A. Sanchez-Cabeza, M. Frignani and F. Alvisi, 2008. Anthropogenic trace metals in the sedimentary record of the Llobregat continental shelf and adjacent Foix Submarine Canyon (northwestern Mediterranean). Mar. Geol., 248 (3-4): 213-227.

Perdue, E.M. and J.F. Koprivnjak, 2007. Using the $\mathrm{C} / \mathrm{N}$ ratio to estimate terrigenous inputs of organic matter to aquatic environments. Estuarine and Coastal Shelf Sciences., 73: 65-72.

Quigg, A., Z.V. Finkel, A.J. Irwin, Y. Rosenthal, T.Y. Ho, J.R. Reinfelder, O. Schofield, F.M.M. Morel and P.G. Falkowski, 2003. The evolutionary inheritance of elemental stoichiometry in marine phytoplankton. Nature, 425: 291-294.

Robbins, J. A., 1978 Geochemical and geophysical applications of radioactive lead isotopes. In: Biogeochemistry of Lead (ed. Nriago, J.P.), pp. 285-393, North Holland, Amsterdam.

Schmidt, S. and J.L. Reyss, 1996. Radium as internal tracer of Mediterranean Outflow Water. J. Geophys. Res., 101: 3589-3596.

Schmidt, S., Tj.C.E. van Weering, J.L. Reyss and P. van Beek, 2002. Seasonal deposition and reworking at the sediment-water interface on the north-western Iberian Margin. Progress in Oceanography, 52: 331-348.

Schmidt, S., H. Howa, A. Mouret, F. Lombard, P. Anschutz and L. Labeyrie, 2009. Particle fluxes and recent sediment accumulation on the Aquitanian margin of Bay of Biscay. Cont. Shelf Res., 29: 1044-1052.

Schroeder, W.H. and J. Munthe, 1998. Atmospheric mercury - An overview. Atmos. Environ., 32 (5): 809-822.

Shotyk, W., M.E. Goodsite, F. Roos-Barraclough, R. Frei, J. Heinemeier, G. Asmund, C. Lohse and T.S. Hansen, 2003. Anthropogenic contribution to atmospheric $\mathrm{Hg}, \mathrm{Pb}$ and $\mathrm{As}$ accumulation recorded by peat cores from southern Greenland and Denmark dated using ${ }^{14} \mathrm{C}$ "bomb pulse curve". Geochim. Cosmochim. Acta, 67: 3991-4011.

Sournia, A., J.M. Brylinski, S. Dallot, P. Lecorre, M. Leveau, L Prieur and C. Froget, 1990. Hydrological fronts off the coasts of France - A review. Oceanologica acta, 13: 413-438. 
Swain, E.B., Engstrom, D.R., Brigham, M.E., Henning, T.A., Brezonik, P.L., 1992. Increasing Rates of Atmospheric Mercury Deposition in Midcontinental North-America. Science, 257 (5071): 784-787. 


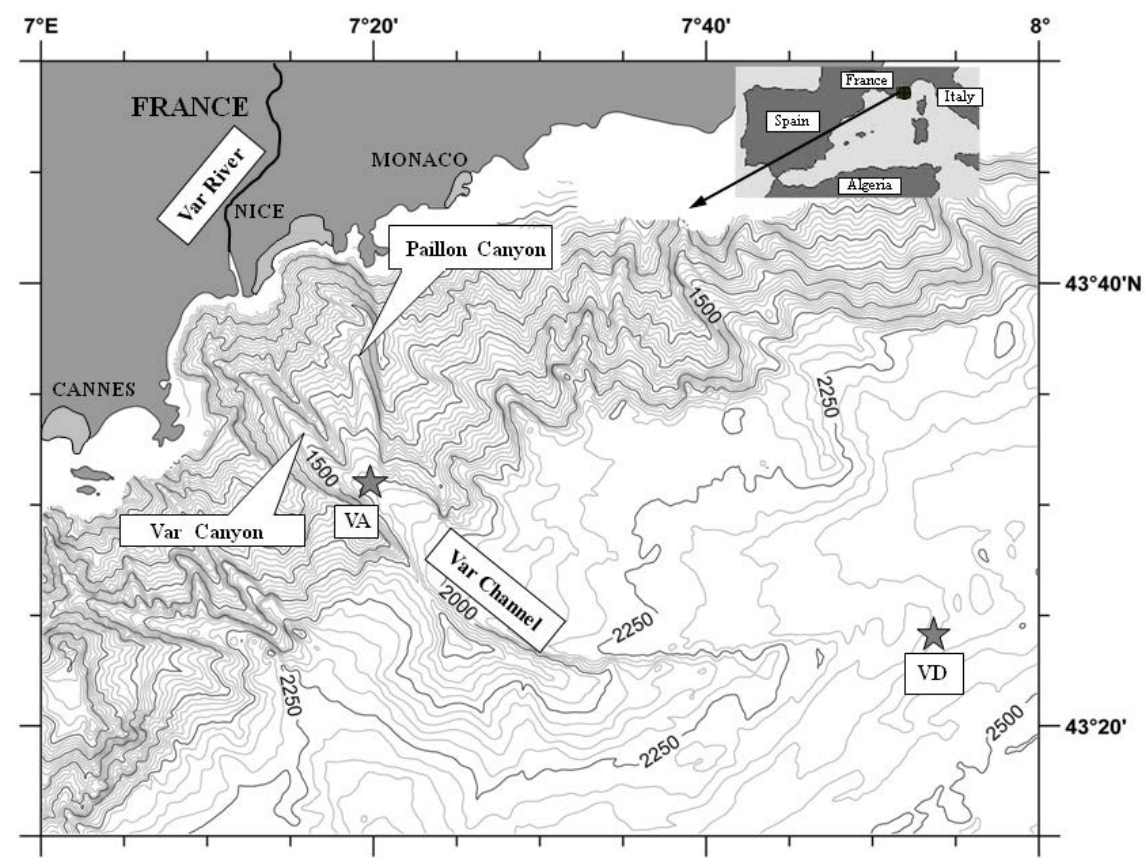

Figure 1. Location of the study sites. Sediment trap mooring station and two interface cores were collected at VA and VD. Map adapted from Khripounoff et al. (2009).

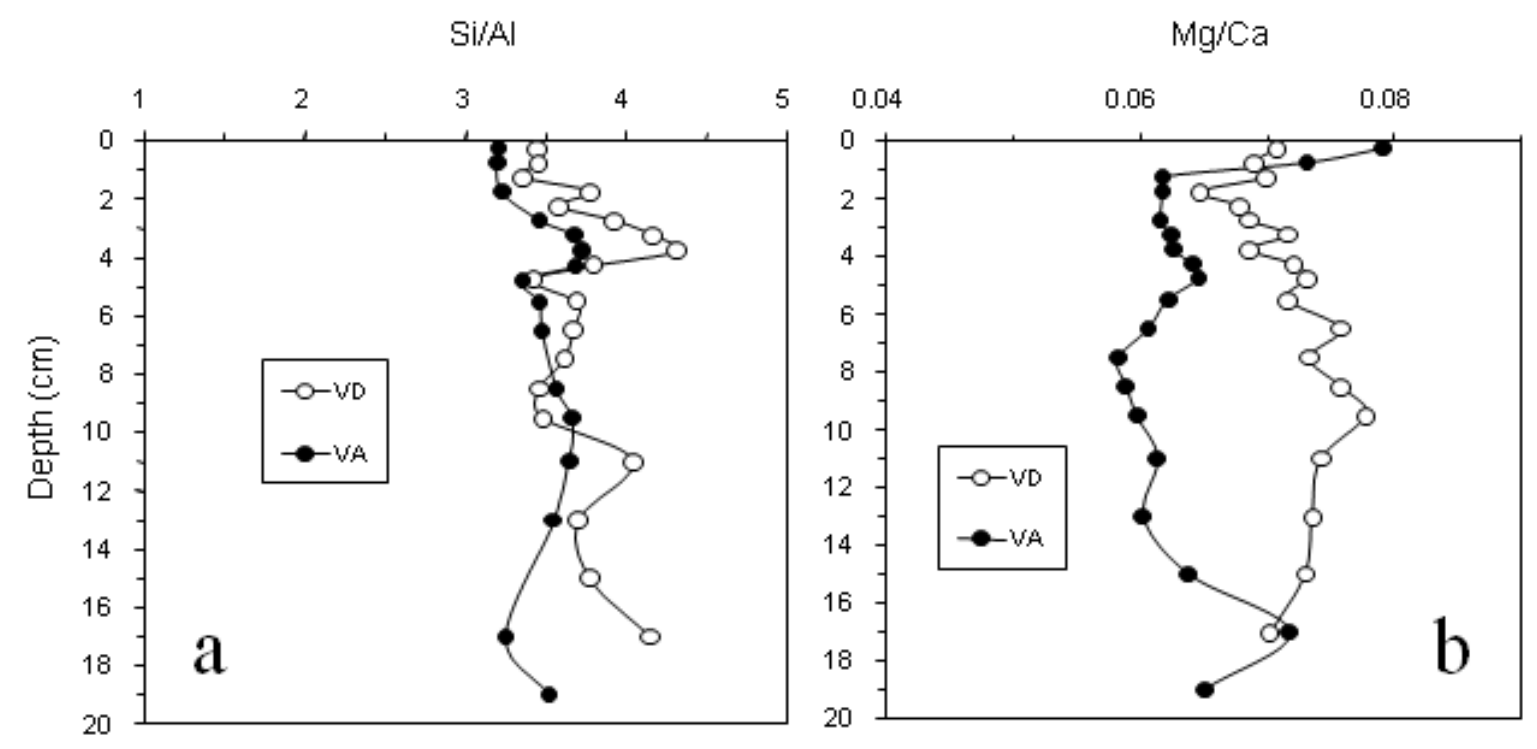

Figure $\mathbf{2 a}$ and $\mathbf{b}$. Down-core variability of $\mathrm{Si} / \mathrm{Al}$ and $\mathrm{Ca} / \mathrm{Mg}$ ratios in the sediment cores from VA in the Var Canyon and VD at the DYFAMED site (ratios in weight). On VA, 3 distinct layers have been documented by Mas (2009) and Mas et al.(2010). "s1" from 0 to $0.8 \mathrm{~cm}$ is a red layer of terrigenous matter; "s2", from 0.8 to $2.1 \mathrm{~cm}$ is a green-brown silt-clay layer (mainly quartz and carbonate) and "s3", from 2.1 to $5.1 \mathrm{~cm}$ is a yellow-brown layer of increasing then decreasing grain size, named "hyperpycnite". In VD core the layer from 2.5 to $4.0 \mathrm{~cm}$ has been documented by martin et al. (2009) as the result of advection material from a large-scale turbidity current triggered by an earthquake that occurred at the end of the XIX ${ }^{\text {th }}$ century (see text). 


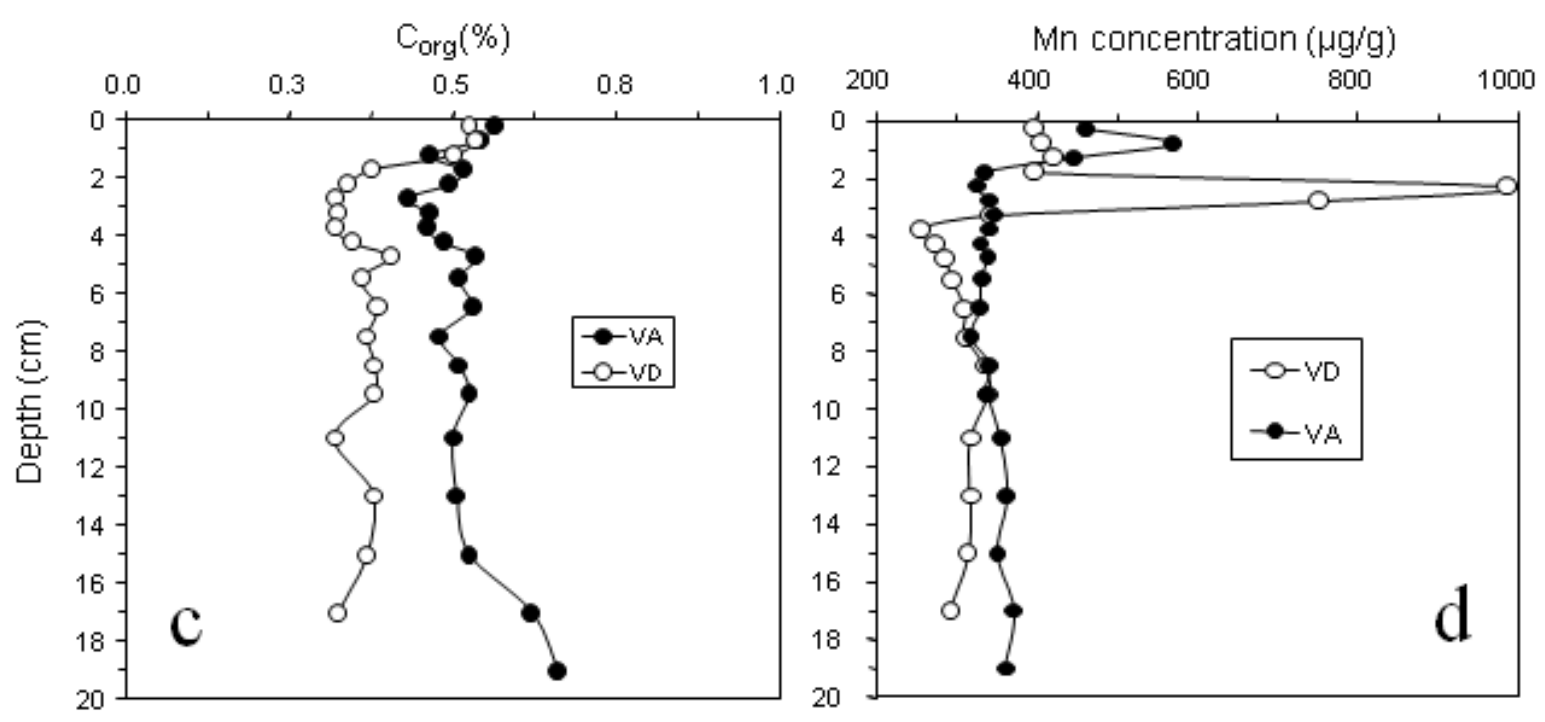

Figure 2c and $\mathbf{d}$. Organic carbon and Mn vertival profiles in the sediment cores from VA in the Var Canyon and VD at the DYFAMED site.

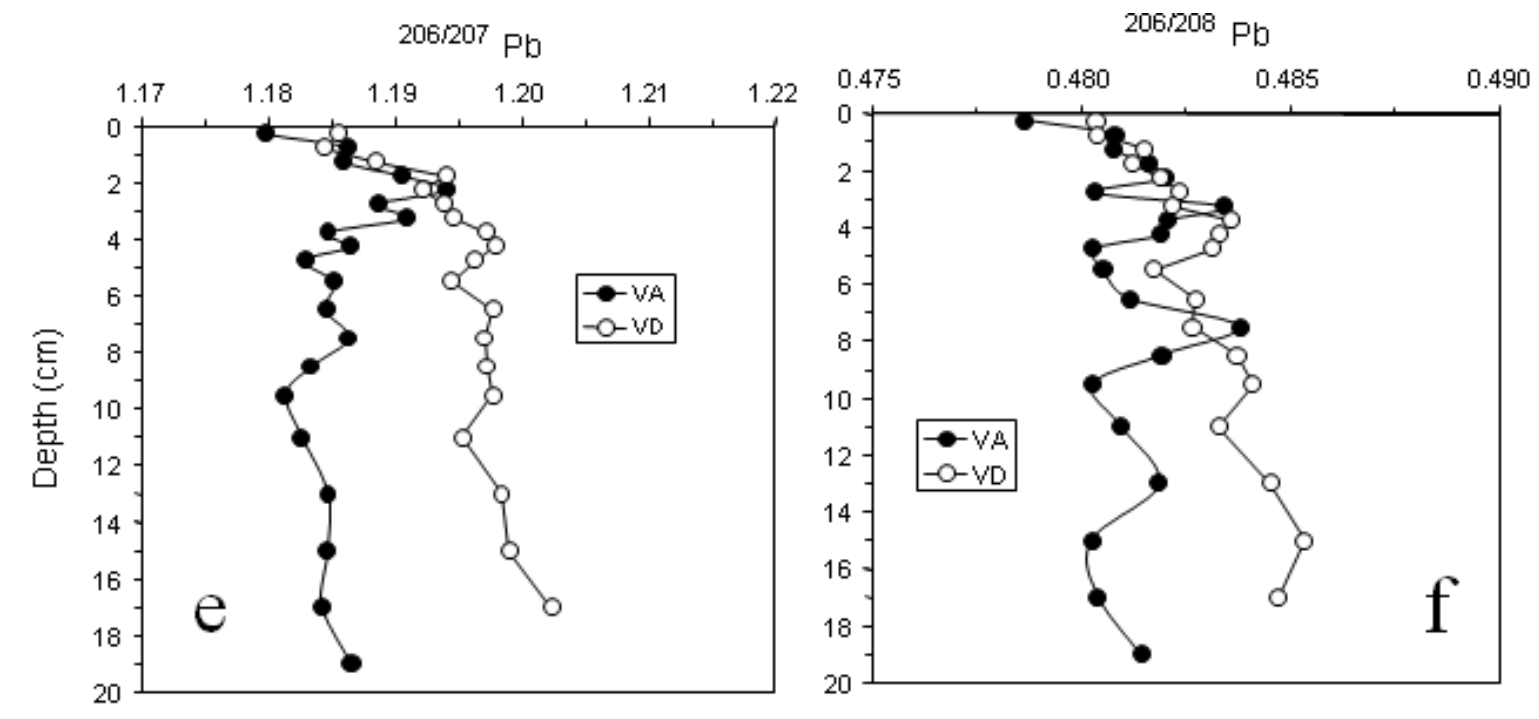

Figure 2e and f. Stable $\mathrm{Pb}$ isotopic ratio $\left(\mathrm{a}:{ }^{206 / 207} \mathrm{~Pb}\right.$; : $\left.{ }^{206 / 208} \mathrm{~Pb}\right)$ variations in the sediment cores from VA in Var Canyon and VD at the DYFAMED site. 
Concentration $(\mu \mathrm{g} / \mathrm{g})$

\section{Concentration $(\mu \mathrm{g} / \mathrm{g})$}

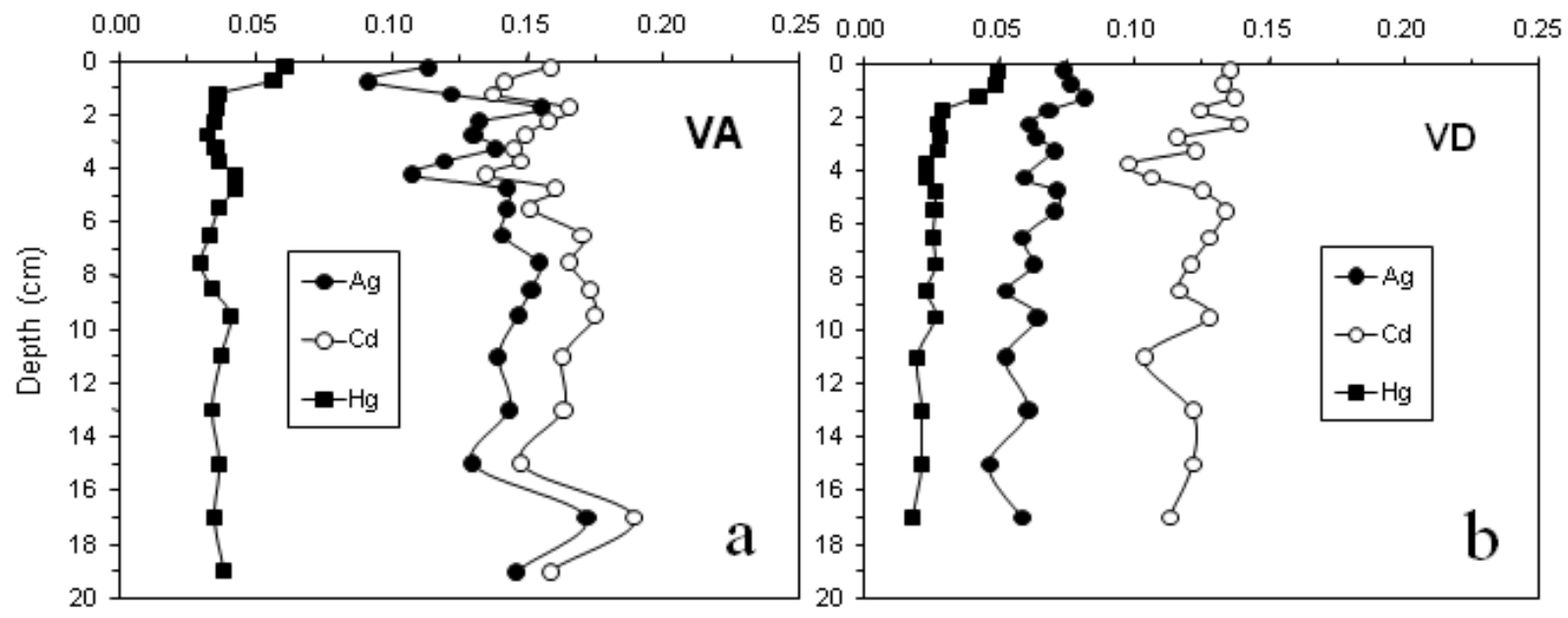

Figure $3 \mathbf{a}$ and $\mathbf{b} . \mathrm{Hg}, \mathrm{Ag}$ and $\mathrm{Cd}$ vertical profiles in the sediment cores from VA in the Var Canyon and VD at the DYFAMED site.
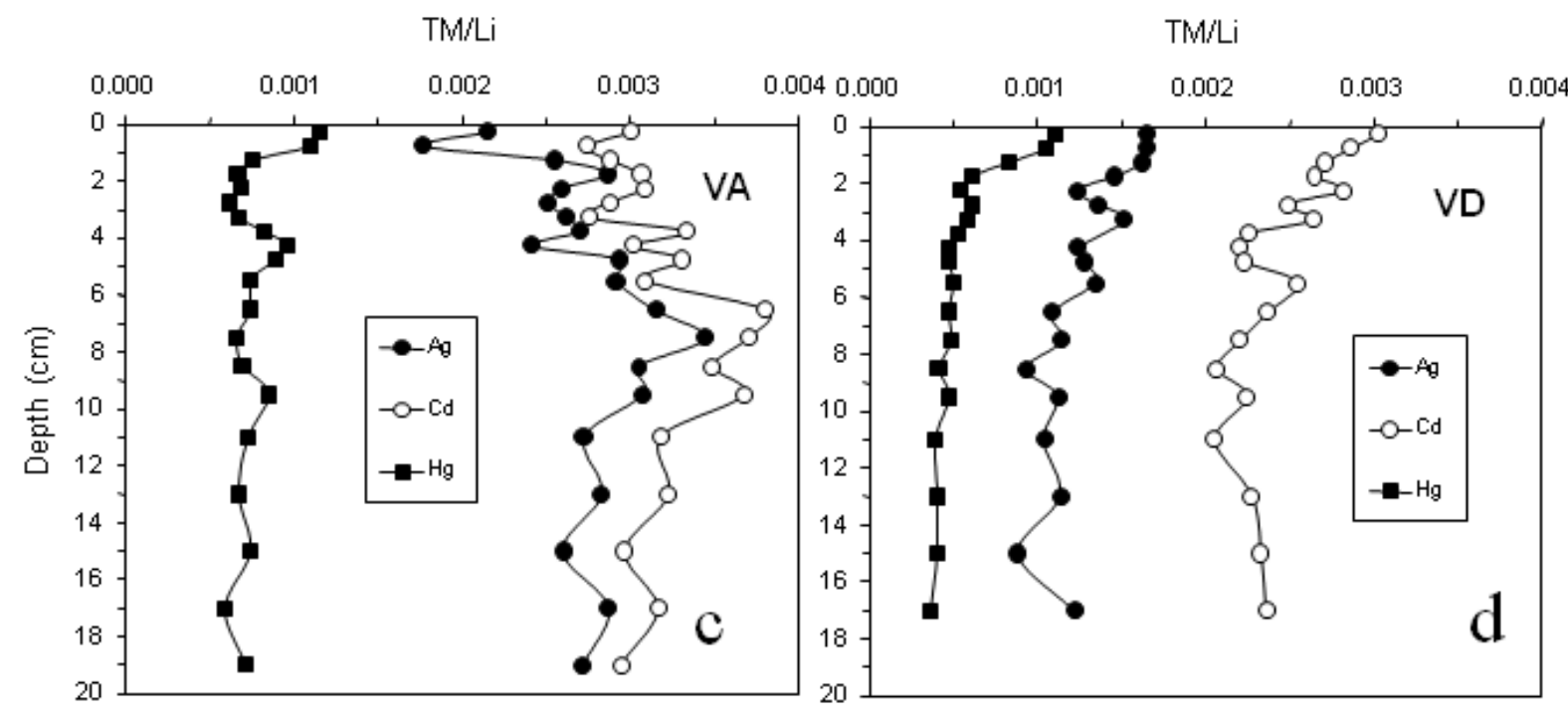

TM/AlX10-4

TM/Al $\times 10^{-4}$
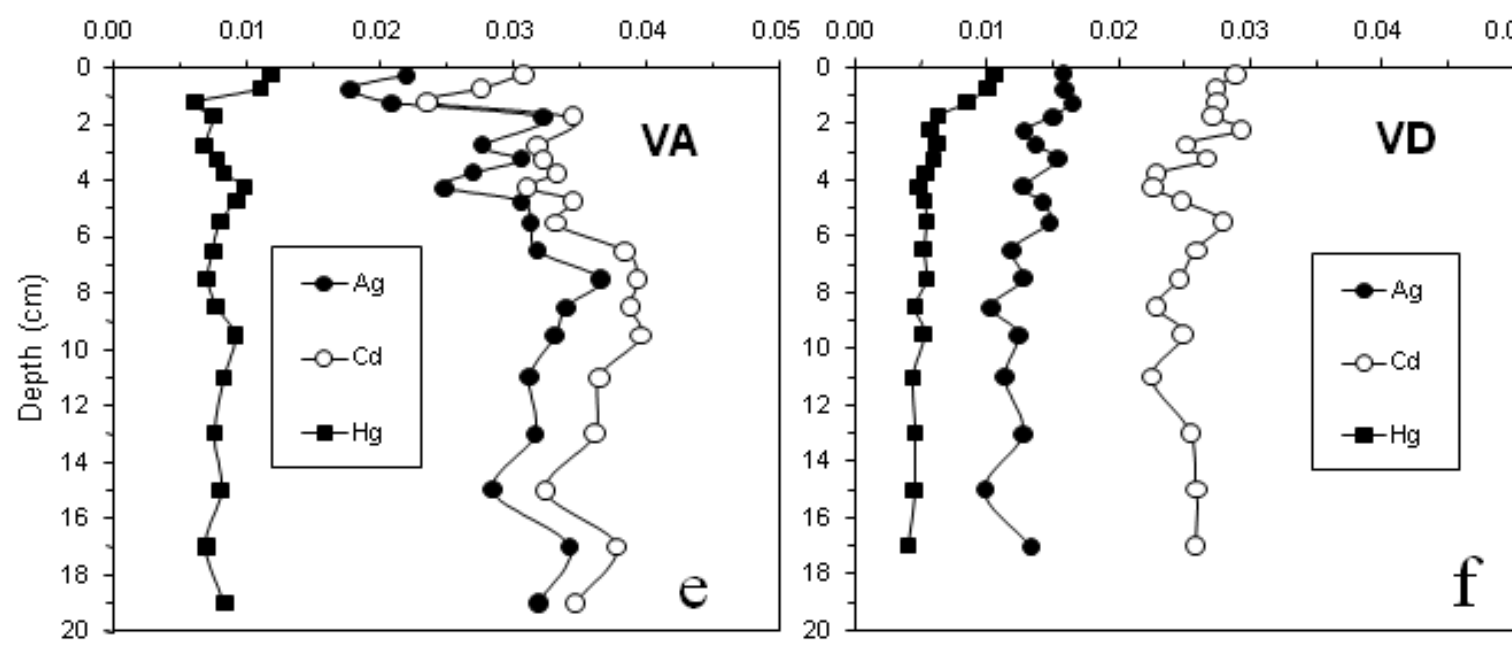

Figure 3c-f. $\mathrm{Hg}, \mathrm{Ag}$ and $\mathrm{Cd}$ to $\mathrm{Li}$ and $\mathrm{Al}$ ratio variations in the sediment cores from $\mathrm{VA}(\mathrm{a}, \mathrm{c})$ in the Var Canyon and VD $(b, d)$ at the DYFAMED site. 


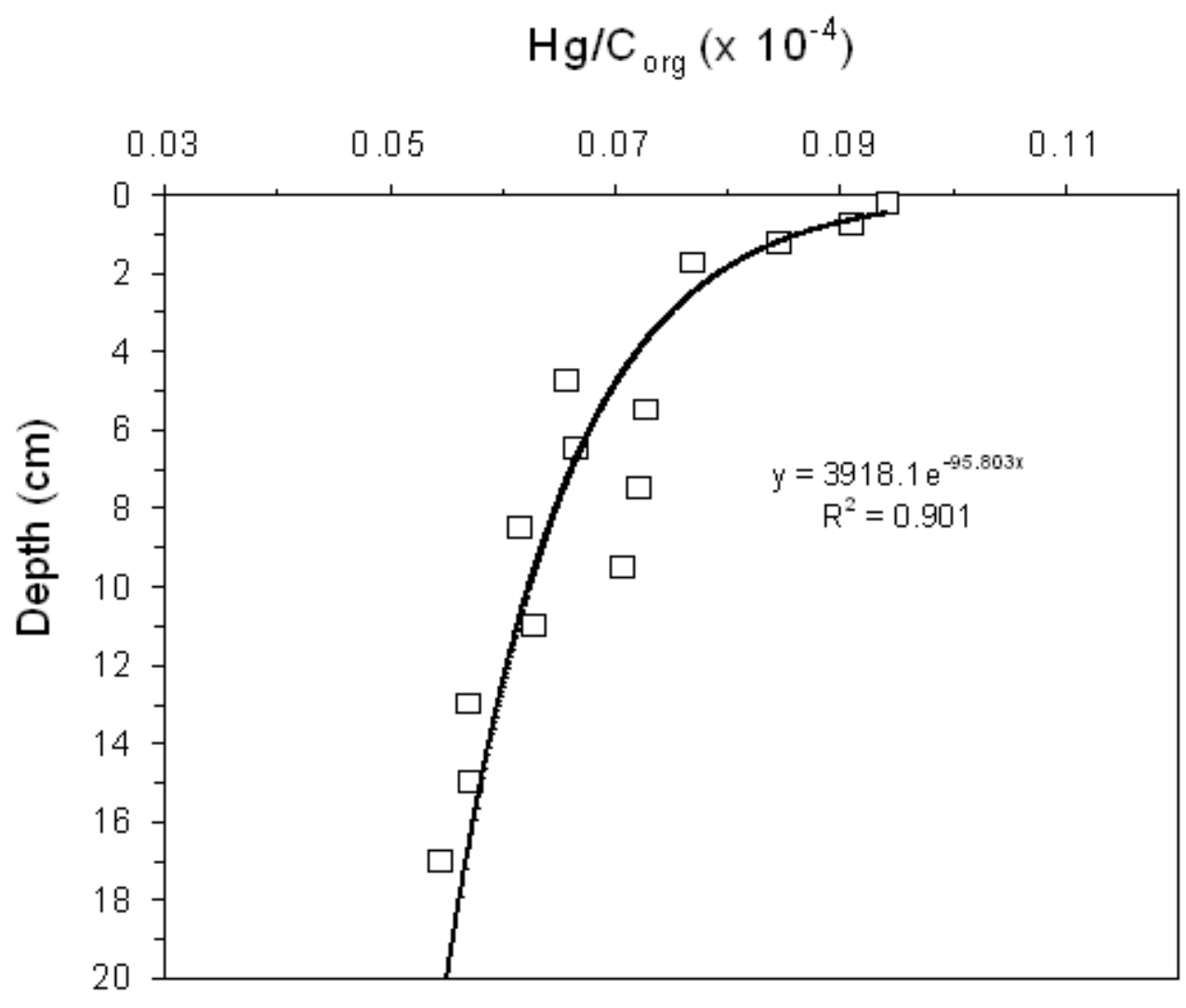

VD

Figure 4. $\mathrm{Hg} / \mathrm{C}_{\text {org }}$ ratio (weight) variations in the sediment core from VD at DYFAMED site (the turbiditic layer has been removed from the graph). 


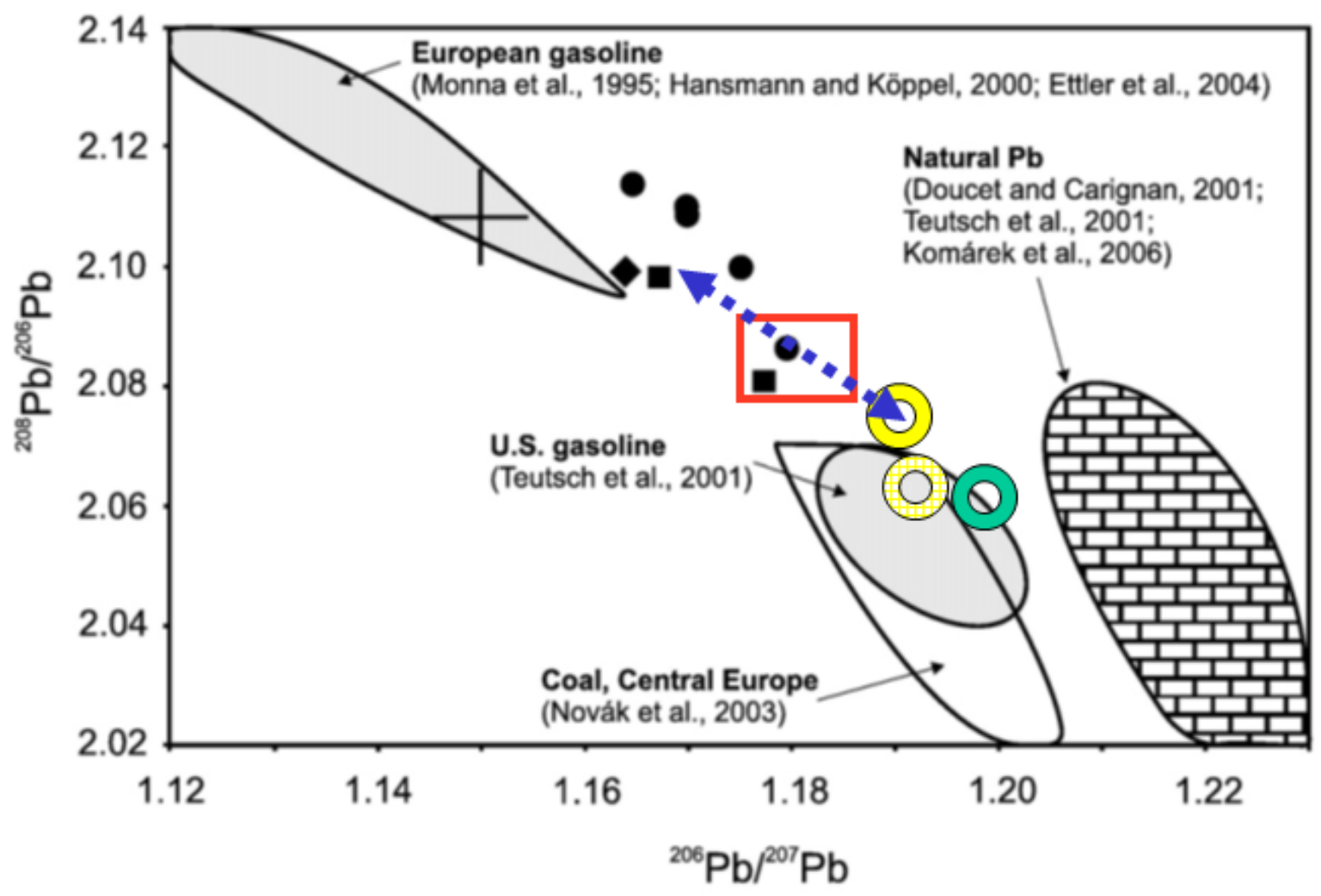

Russian $\mathrm{Pb}$ ores (Mukai et al., 2001)

APC residues from $\mathrm{Pb}$ metallurgy, Czech Rep. (Ettler et al., 2004)

- Czech galena (Ettler et al., 2004)

Fly ashes from municipal waste combustors, France, Switzerland (Hansmann and Köppel, 2000; Carignan et al., 2005)

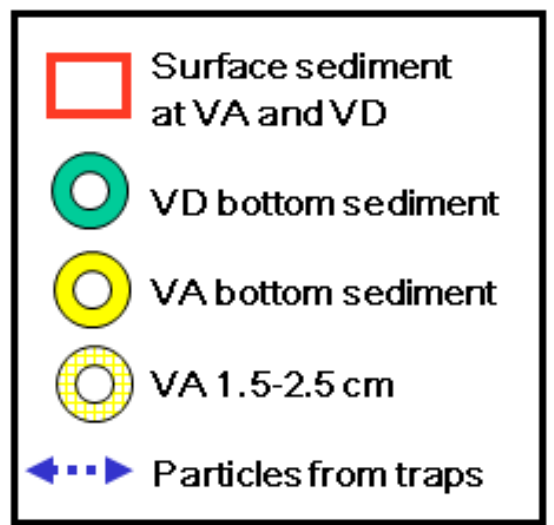

From Komarek et al. (2008)

Figure 5. Isotopic composition of $\mathrm{Pb}$ in sediment and particles from traps. VA: Var Canyon site and VD: DYFAMED site. Graph adapted from Komarek et al. (2008). 
Table 1. Element composition of particles collected in sediment traps. (1) Depth of the water column at the mooring site; (2) Position of the sediment trap from the sea bottom. VA: canyon (Upper Valley of the Var turbidite system); VD: Eastern par of the Var Sedimentary Ridge (DYFAMED site). See figure 1 for locations.

\begin{tabular}{|c|c|c|c|c|c|c|c|c|c|c|c|c|c|c|c|c|c|c|c|}
\hline Site & Depth $^{1}$ & Position $^{2}$ & $\mathrm{C}_{\text {org }}$ & $\mathrm{N}$ & $\mathrm{Li}$ & V & $\mathrm{Cr}$ & $\mathrm{Mn}$ & $\mathrm{Ni}$ & $\mathrm{Cu}$ & $\mathrm{Zn}$ & $\mathrm{Ag}$ & $\mathrm{Cd}$ & $\mathrm{Pb}$ & $\mathrm{Hg}$ & Al & $\mathrm{Mg}$ & $\mathrm{Ca}$ & $\mathrm{Fe}$ \\
\hline & $m$ & $m$ & $\%$ & $\%$ & $\mu g / g$ & $\mu g / g$ & $\mu g / g$ & $\mu g / g$ & $\mu g / g$ & $\mu g / g$ & $\mu g / g$ & $\mu g / g$ & $\mu g / g$ & $\mu g / g$ & $\mu g / g$ & $\%$ & $\%$ & $\%$ & $\%$ \\
\hline VA1 & 1850 & 20 & 0.84 & 0.0147 & 62 & 87 & 68 & 390 & 38 & 25 & 81 & 0.146 & 0.169 & 21 & 0.041 & 5.19 & 1.08 & 16.8 & 2.3 \\
\hline VD1 & 2400 & 20 & 0.96 & 0.1470 & 64 & 113 & 140 & 741 & 79 & 85 & 151 & 0.176 & 0.221 & 62 & 0.181 & 6.22 & 1.56 & 11.6 & 3.0 \\
\hline VD2 & 2400 & 20 & 2.56 & 0.3150 & 72 & 108 & 94 & 785 & 57 & 47 & 107 & 0.121 & 0.177 & 44 & 0.088 & 5.84 & 1.35 & 14.4 & 2.6 \\
\hline
\end{tabular}


Table 2. Elemental composition of sediment at the VA site from the Upper Valley of the Var canyon (see figure 1 for locations).

\begin{tabular}{|c|c|c|c|c|c|c|c|c|c|c|c|c|c|c|c|c|c|c|}
\hline $\begin{array}{c}\text { Level } \\
\mathrm{cm}\end{array}$ & $\begin{array}{c}\mathrm{C}_{\text {org }} \\
\%\end{array}$ & $\begin{array}{l}\mathrm{N} \\
\%\end{array}$ & $\begin{array}{c}\mathrm{Li} \\
\mu g / g\end{array}$ & $\begin{array}{c}\mathrm{V} \\
\mu g / g\end{array}$ & $\begin{array}{c}\mathrm{Cr} \\
\mu g / g\end{array}$ & $\begin{array}{c}\mathrm{Mn} \\
\mu g / g\end{array}$ & $\begin{array}{c}\mathrm{Ni} \\
\mu g / g\end{array}$ & $\begin{array}{c}\mathrm{Cu} \\
\mu \mathrm{g} / \mathrm{g}\end{array}$ & $\begin{array}{c}\mathrm{Zn} \\
\mu \mathrm{g} / \mathrm{g}\end{array}$ & $\begin{array}{c}\mathrm{Ag} \\
\mu g / g\end{array}$ & $\begin{array}{c}\mathrm{Cd} \\
\mu g / g\end{array}$ & $\begin{array}{c}\mathrm{Pb} \\
\mu g / g\end{array}$ & $\begin{array}{c}\mathrm{Hg} \\
\mu g / g\end{array}$ & $\begin{array}{c}\mathrm{Mg} \\
\%\end{array}$ & $\begin{array}{l}\text { Al } \\
\%\end{array}$ & $\begin{array}{l}\mathrm{Si} \\
\%\end{array}$ & $\begin{array}{c}\mathrm{Ca} \\
\%\end{array}$ & $\begin{array}{l}\mathrm{Fe} \\
\%\end{array}$ \\
\hline 0.25 & 0.57 & 0.063 & 52.6 & 77 & 65.5 & 462 & 38.7 & 23.9 & 78.2 & 0.11 & 0.16 & 22.66 & .061 & 1.41 & 5.15 & 16.5 & 17.8 & 5.15 \\
\hline 0.75 & 0.54 & 058 & 51.6 & 75 & 64.5 & 569 & 39.3 & 24.8 & 83.9 & 0.09 & 0.14 & 22.73 & 0.057 & 1.34 & 5.13 & 16.4 & 18.3 & 5.13 \\
\hline 1.25 & .47 & 046 & 47.8 & 65 & 52.2 & 444 & 31.5 & 21.0 & 71.7 & 0.12 & 0.14 & 17.87 & 0.036 & 1.24 & 5.84 & 16.2 & 20.0 & 5.84 \\
\hline 1.75 & 0.52 & 048 & 54.0 & 71 & 54.5 & 333 & 32.9 & 21.4 & 75.7 & 0.16 & 0.17 & 18.55 & 0.036 & 1.19 & 4.81 & 15.5 & 19.3 & 481 \\
\hline 2.25 & 0.50 & 046 & 50.9 & 68 & 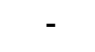 & 325 & 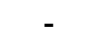 & - & - & 0.13 & 0.16 & & 0.035 & & - & 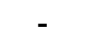 & - & 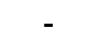 \\
\hline 2.75 & 0.43 & .037 & 51.8 & 66 & 52.9 & 340 & 33.3 & 21.1 & 71.1 & 0.13 & 0.15 & 18.95 & 0.032 & 1.18 & 4.70 & 16.2 & 19.3 & 4.70 \\
\hline 3.25 & 0.47 & 046 & 52.7 & 68 & 55.2 & 346 & 34.0 & 21.2 & 71.8 & 0.14 & 0.15 & 19.82 & 0.035 & 1.13 & 4.51 & 16.6 & 18.01 & 4.51 \\
\hline 3.75 & 0.46 & .042 & 44.3 & 67 & 53.7 & 340 & 32.8 & 21.2 & 67.7 & 0.12 & 0.15 & 19.35 & 0.037 & 1.09 & 4.44 & 16.5 & 17.4 & 4.44 \\
\hline 4.25 & 0.49 & 0.044 & 44.8 & 63 & 53.5 & 329 & 32.1 & 20.1 & 70.2 & 0.11 & 0.14 & 19.31 & 0.043 & 1.09 & 4.35 & 16.0 & 17.0 & 4.35 \\
\hline 4.75 & 0.54 & 049 & 48.5 & 70 & 57.3 & 339 & 32.9 & 20.4 & 71.6 & 0.14 & 0.16 & 20.01 & 0.043 & 1.12 & 4.65 & 15.6 & 17.3 & 4.65 \\
\hline 5.50 & 0.51 & 047 & 49.0 & 68 & 53.8 & 331 & 31.7 & 19.9 & 69.6 & 0.14 & 0.15 & 19.46 & 0.037 & 1.12 & 4.56 & 15.7 & 18.0 & 4.56 \\
\hline 6.50 & 0.53 & 0.045 & 44.7 & 70 & 52.9 & 328 & 30.2 & 20.5 & 66.8 & 0.14 & 0.17 & 16.77 & 0.033 & 1.10 & 4.43 & 15.4 & 18.2 & 4.43 \\
\hline 7.50 & 0.48 & 041 & 44.8 & 64 & 49.9 & 317 & 30.2 & 20.7 & 70.3 & 0.15 & 0.17 & 17.07 & 0.030 & 1.05 & 4.22 & - & 18.08 & 4.22 \\
\hline 8.50 & 0.51 & 0.044 & 49.6 & 71 & 54.1 & 341 & 31.7 & 22.8 & 72.4 & 0.15 & 0.17 & 17.99 & 0.034 & 1.06 & 4.45 & 15.9 & 18.1 & 4.45 \\
\hline 9.50 & 0.53 & .044 & & 68 & 54.0 & 337 & 31.6 & 21.6 & 73.4 & & 0.18 & & & 1.07 & 4.43 & 16.2 & 17.9 & \\
\hline 11 & 0.50 & 044 & 51.2 & 72 & 55.8 & 354 & 32.8 & 20.6 & 72.2 & 0.14 & 0.16 & 19.13 & 0.037 & 1.08 & 4.47 & 16.3 & 17.6 & 4.47 \\
\hline 13 & 0.51 & 0.045 & 50.6 & 71 & 58.4 & 362 & 33.5 & 21.8 & 73.2 & 0.14 & 0.16 & 19.21 & 0.034 & 1.08 & 4.52 & 16.0 & 18.0 & 4.52 \\
\hline 15 & 0.53 & 045 & 49.9 & 70 & 57.8 & 351 & 33.8 & & 73.9 & 0.13 & 0.15 & 19.60 & 0.037 & 1.11 & 4.57 & 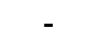 & 17.4 & 4.57 \\
\hline 17 & 0.62 & 0.050 & 59.8 & 79 & 61.3 & 372 & 36.7 & 25.6 & 83.7 & 0.17 & 0.19 & & 0.035 & 1.19 & 5.02 & 16.3 & 16.6 & 5.02 \\
\hline 19 & 0.66 & .049 & 53.8 & 73 & 58.4 & 361 & 34.7 & 23.9 & 73.7 & 0.15 & 0.16 & 21.35 & 0.038 & 1.13 & 4.57 & 16.1 & 17.3 & 4.57 \\
\hline
\end{tabular}


Table 3. Element composition of marine sediment at the VD site (DYFAMED, see figure 1 for location).

\begin{tabular}{|c|c|c|c|c|c|c|c|c|c|c|c|c|c|c|c|c|c|c|}
\hline Level & $\mathrm{C}_{\text {org }}$ & $N$ & $\mathrm{Li}$ & V & $\mathrm{Cr}$ & $\mathrm{Mn}$ & $\mathrm{Ni}$ & $\mathrm{Cu}$ & $Z n$ & $\mathrm{Ag}$ & $\mathrm{Cd}$ & $\mathrm{Pb}$ & $\mathrm{Hg}$ & $\mathrm{Mg}$ & $\mathrm{Al}$ & $\mathrm{Si}$ & $\mathrm{Ca}$ & $\mathrm{Fe}$ \\
\hline $\mathrm{cm}$ & $\%$ & $\%$ & $\mu g / g$ & $\mu g / g$ & $\mu g / g$ & $\mu g / g$ & $\mu g / g$ & $\mu g / g$ & $\mu g / g$ & $\mu g / g$ & $\mu g / g$ & $\mu g / g$ & $\mu g / g$ & $\%$ & $\%$ & $\%$ & $\%$ & $\%$ \\
\hline 0.25 & 0.53 & 0.052 & 45 & 72 & 56 & 396 & 30.6 & 19.4 & 64 & 0.07 & 0.14 & 20.3 & 0.049 & 1.17 & 4.68 & 16.2 & 16.5 & 2.14 \\
\hline 0.75 & 0.54 & 0.051 & 46 & 75 & 58 & 406 & 31.3 & 20.2 & 72 & 0.08 & 0.13 & 20.7 & 0.049 & 1.13 & 4.85 & 16.7 & 16.4 & 2.20 \\
\hline 1.25 & 0.50 & 0.050 & 51 & 80 & 60 & 421 & 31.7 & 20.9 & 67 & 0.08 & 0.14 & 19.8 & 0.042 & 1.13 & 4.98 & 16.7 & 16.1 & 2.22 \\
\hline 1.75 & 0.38 & 0.036 & 47 & 69 & 53 & 397 & 29.0 & 17.2 & 59 & 0.07 & 0.12 & 17.1 & 0.029 & 1.07 & 4.57 & 17.3 & 16.5 & 2.11 \\
\hline 2.25 & 0.34 & 0.035 & 49 & 74 & 57 & 987 & 35.2 & 19.3 & 63 & 0.06 & 0.14 & 17.9 & 0.027 & 1.10 & 4.75 & 17.0 & 16.3 & 2.21 \\
\hline 2.75 & 0.32 & 0.033 & 47 & 69 & 55 & 750 & 32.5 & 17.5 & 60 & 0.06 & 0.12 & 17.1 & 0.029 & 1.09 & 4.62 & 18.1 & 15.9 & 2.25 \\
\hline 3.25 & 0.33 & 0.036 & 46 & 69 & 56 & 341 & 32.3 & 17.4 & 57 & 0.07 & 0.12 & 16.5 & 0.027 & 1.09 & 4.58 & 19.1 & 15.2 & 2.28 \\
\hline 3.75 & 0.32 & 0.030 & 44 & 63 & 50 & 255 & 29.5 & 15.1 & 52 & 0.12 & 0.10 & 15.2 & 0.023 & 1.06 & 4.30 & 18.5 & 15.5 & 2.28 \\
\hline 4.25 & 0.35 & 0.035 & 48 & 71 & 57 & 271 & 34.1 & 16.1 & 57 & 0.06 & 0.11 & 15.6 & 0.023 & 1.16 & 4.70 & 17.9 & 16.0 & 3.06 \\
\hline 4.75 & 0.41 & 0.041 & 56 & 88 & 69 & 284 & 38.2 & 20.9 & 65 & 0.07 & 0.13 & 15.2 & 0.027 & 1.14 & 5.04 & 17.2 & 15.6 & 2.36 \\
\hline 5.5 & 0.36 & 0.037 & 53 & 81 & 64 & 294 & 36.3 & 19.7 & 62 & 0.07 & 0.14 & 15.0 & 0.026 & 1.12 & 4.79 & 17.7 & 15.7 & 2.13 \\
\hline 6.5 & 0.39 & 0.038 & 54 & 83 & 66 & 310 & 37.5 & 20.1 & 63 & 0.06 & 0.13 & 15.6 & 0.026 & 1.18 & 4.94 & 18.1 & 15.6 & 2.16 \\
\hline 7.5 & 0.37 & 0.039 & 55 & 83 & 65 & 312 & 36.6 & 19.8 & 63 & 0.06 & 0.12 & 15.3 & 0.027 & 1.16 & 4.91 & 17.7 & 15.8 & 2.20 \\
\hline 8.5 & 0.38 & 0.042 & 57 & 86 & 67 & 334 & 38.6 & 19.1 & 64 & 0.05 & 0.12 & 15.6 & 0.023 & 1.19 & 5.13 & 17.7 & 15.8 & 2.39 \\
\hline 9.5 & 0.38 & 0.043 & 57 & 87 & 68 & 340 & 38.4 & 22.3 & 65 & 0.06 & 0.13 & 15.7 & 0.027 & 1.20 & 5.15 & 17.9 & 15.5 & 2.32 \\
\hline 11 & 0.32 & 0.034 & 51 & 73 & 57 & 318 & 32.4 & 16.8 & 58 & 0.05 & 0.10 & 14.6 & 0.020 & 1.13 & 4.60 & 18.6 & 15.3 & 2.19 \\
\hline 13 & 0.38 & 0.038 & 53 & 76 & 57 & 316 & 32.2 & 17.7 & 63 & 0.06 & 0.12 & 14.5 & 0.022 & 1.15 & 4.77 & 17.7 & 15.6 & 2.19 \\
\hline 15 & 0.37 & 0.039 & 52 & 74 & כו & 313 & 32.2 & 16.4 & 60 & 0.05 & 0.12 & 14.9 & 0.021 & 1.13 & 4.70 & 17.7 & 15.4 & 2.16 \\
\hline 17 & 0.33 & 0.032 & 48 & 66 & 52 & 292 & 28.5 & 15.1 & 54 & 0.06 & 0.11 & 14.8 & 0.018 & 1.07 & 4.38 & 18.2 & 15.3 & 2.04 \\
\hline
\end{tabular}


Table $4 \mathrm{~Pb}$ isotopic ratios in sediment cores and particles for sediment traps (see figure 1 for locations).

\begin{tabular}{cccc}
\hline Type of sample & Depth $(\mathrm{cm})$ & ${ }^{206} \mathrm{~Pb} /{ }^{207} \mathrm{~Pb}$ & ${ }^{206} \mathrm{~Pb} /{ }^{208} \mathrm{~Pb}$ \\
\hline VA core & 0.25 & 1.180 & 0.479 \\
VA core & 0.75 & 1.186 & 0.481 \\
VA core & 1.25 & 1.186 & 0.481 \\
VA core & 1.75 & 1.191 & 0.482 \\
VA core & 2.75 & 1.189 & 0.480 \\
VA core & 3.25 & 1.191 & 0.483 \\
VA core & 3.75 & 1.185 & 0.482 \\
VA core & 4.25 & 1.186 & 0.482 \\
VA core & 4.75 & 1.183 & 0.480 \\
VA core & 5.5 & 1.185 & 0.481 \\
VA core & 6.5 & 1.185 & 0.481 \\
VA core & 7.5 & 1.186 & 0.484 \\
VA core & 8.5 & 1.183 & 0.482 \\
VA core & 9.5 & 1.181 & 0.480 \\
VA core & 11 & 1.183 & 0.481 \\
VA core & 13 & 1.185 & 0.482 \\
VA core & 15 & 1.185 & 0.480 \\
VA core & 17 & 1.184 & 0.480 \\
VA core & 19 & 1.187 & 0.481 \\
VD core & & & \\
VD core & 0.25 & 1.185 & 0.480 \\
VD core & 0.75 & 1.184 & 0.480 \\
VD core & 1.25 & 1.188 & 0.482 \\
VD core & 1.75 & 1.194 & 0.481 \\
VD core & 2.25 & 1.192 & 0.482 \\
VD core & 2.75 & 1.194 & 0.482 \\
VD core & 3.25 & 1.195 & 0.482 \\
VD core & 3.75 & 1.197 & 0.484 \\
VD core & 4.25 & 1.198 & 0.483 \\
VD core & 4.75 & 1.196 & 0.483 \\
VD core & 5.5 & 1.194 & 0.482 \\
VD core & 6.5 & 1.198 & 0.483 \\
VD core & 7.5 & 1.197 & 0.483 \\
VD core & 8.5 & 1.197 & 0.484 \\
VD core & 9.5 & 1.198 & 0.484 \\
VD core & 11 & 1.195 & \\
VD core & 13 & 1.198 & \\
VD core & 15 & & \\
& & & 0.485 \\
\hline
\end{tabular}




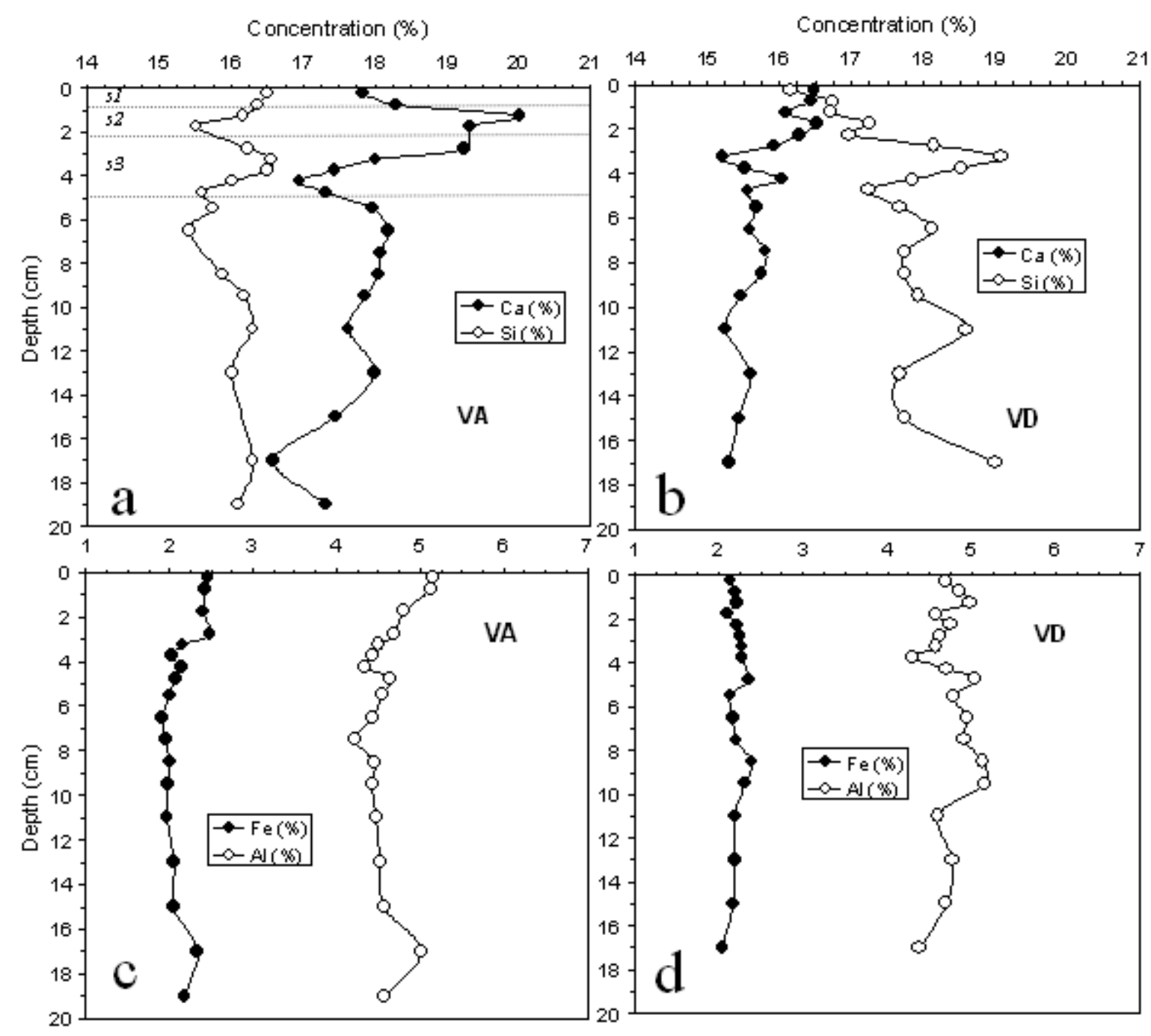

Figure S1. Major element ( $\mathrm{Ca}, \mathrm{Mg}, \mathrm{Si}, \mathrm{Al}$, and $\mathrm{Fe}$ ) concentration variations in sediment cores from $\mathrm{VA}$ $(a, c)$ in the Var Canyon and VD (b, d) at the DYFAmED site. On VA, 3 distinct layers have been documented by Mas (2009) and Mas et al.(2010). "s1" from 0 to $0.8 \mathrm{~cm}$ is a red layer of terrigenous matter; "s2", from 0.8 to $2.1 \mathrm{~cm}$ is a green-brown silt-clay layer (mainly quartz and carbonate) and "s3", from 2.1 to $5.1 \mathrm{~cm}$ is a yellow-brown layer of increasing then decreasing grain size, named "hyperpycnite". In VD core the layer from 2.5 to $4.0 \mathrm{~cm}$ has been documented by Martin et al. (2009) as the result of advection material from a large-scale turbidity current triggered by an earthquake that occurred at the end of the XIX ${ }^{\text {th }}$ century (see text). 
Concentration $(\mu \mathrm{g} / \mathrm{g})$

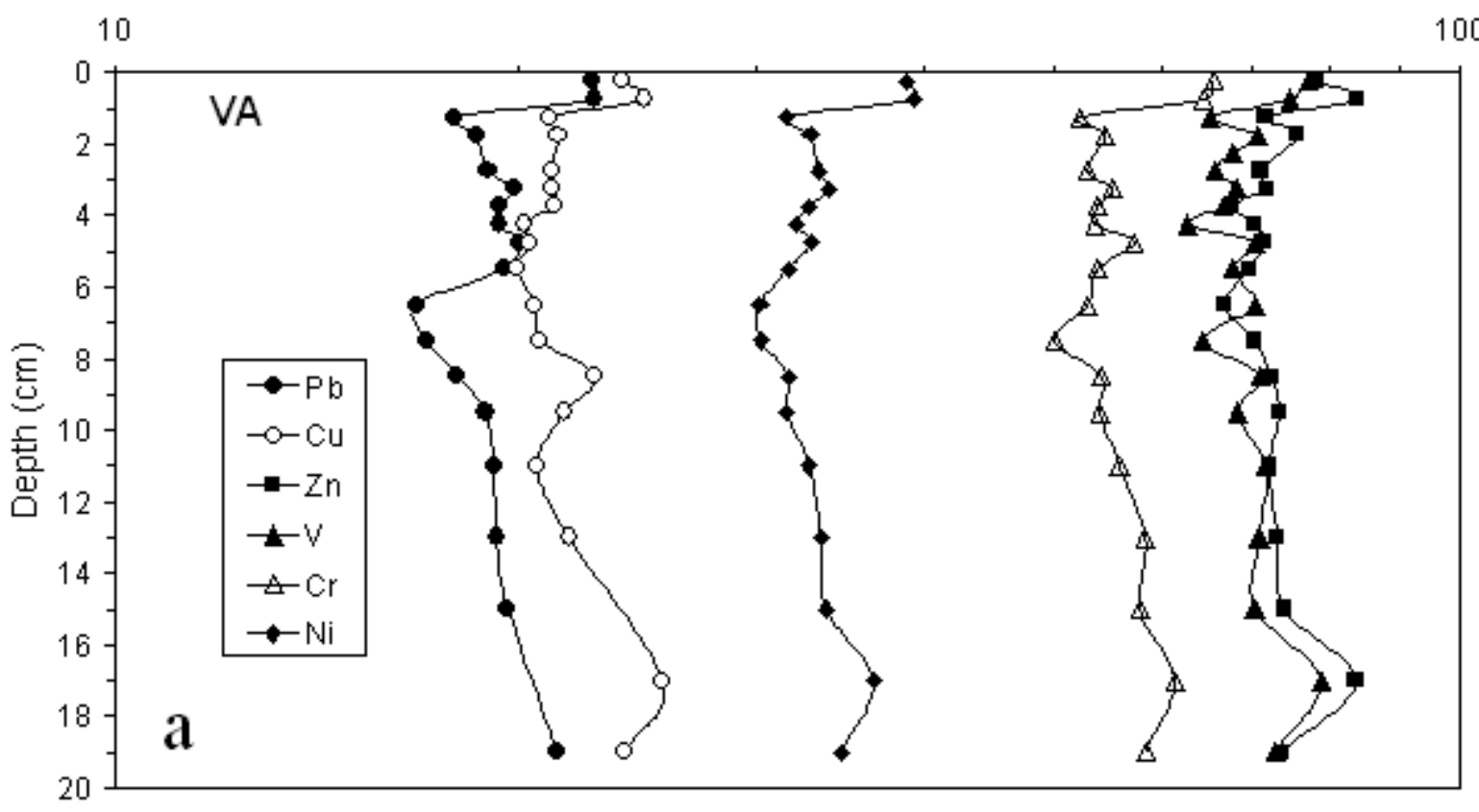

Concentration $(\mu \mathrm{g} / \mathrm{g})$

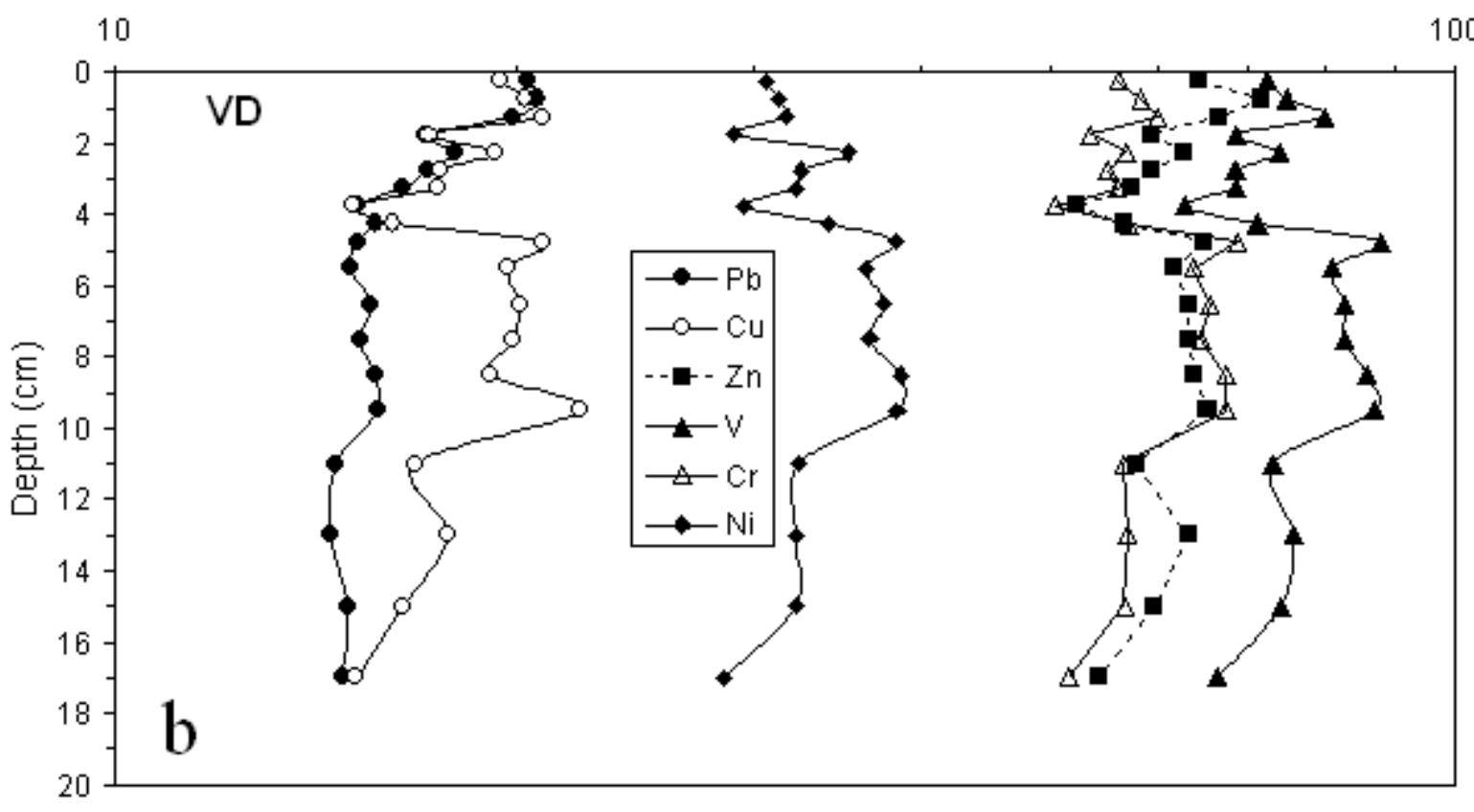

Figure S2. Trace metal $(\mathrm{Li}, \mathrm{V}, \mathrm{Cr}, \mathrm{Cu}, \mathrm{Zn}$ and $\mathrm{Pb})$ concentration variations in sediment cores from $\mathrm{VA}$ $(a, c)$ in the Var Canyon and VD $(b, d)$ at the DYFAMED site. 

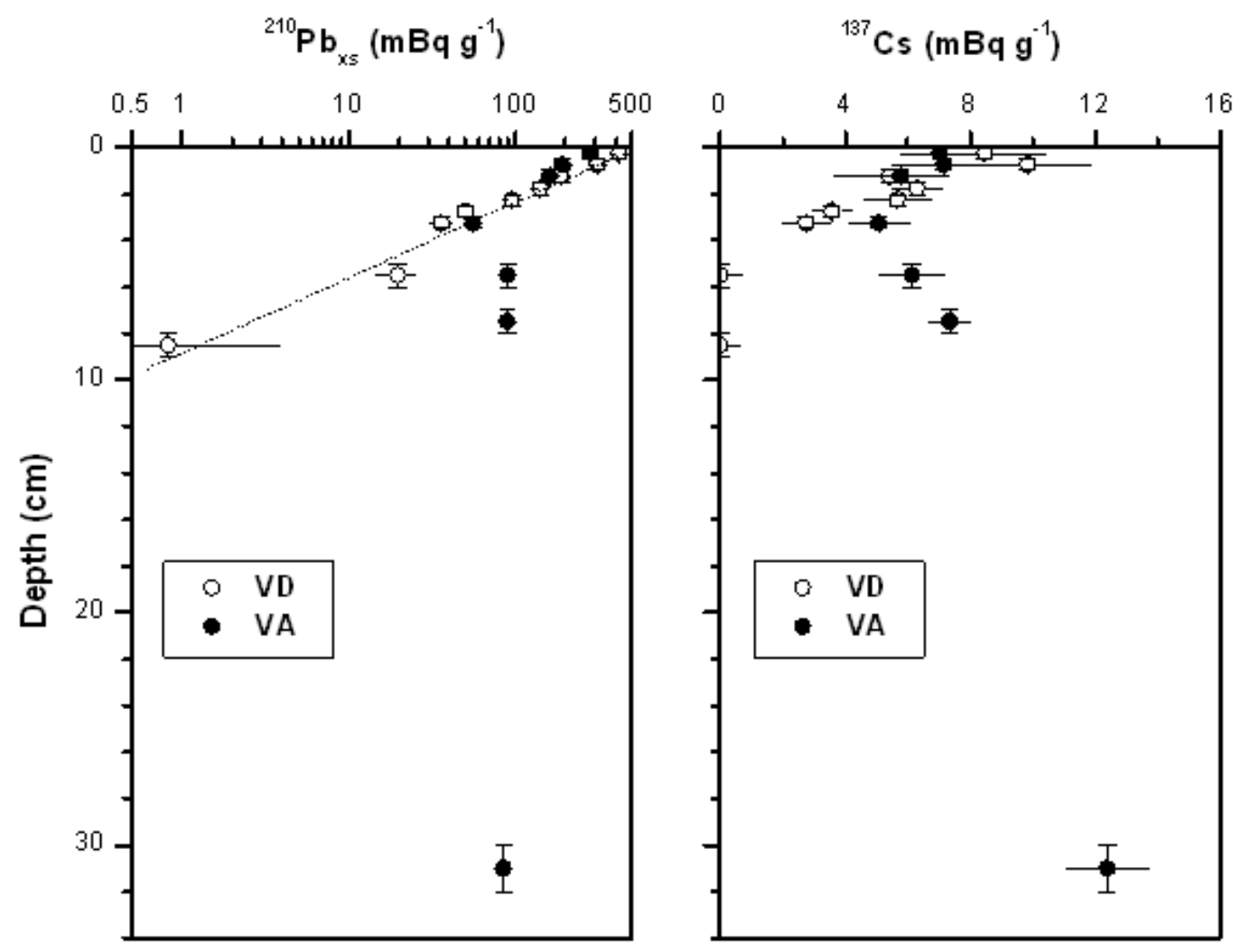

Figure S3. Profiles of ${ }^{210} \mathrm{~Pb}_{\mathrm{xs}}$ and of ${ }^{137} \mathrm{Cs}$ with depth in cores VA (dark circle) and VD (open circle) collected during Envar-4 cruise. Vertical bars represent the layer thickness; horizontal bars to the errors on radionuclide activities. The dashed line on the ${ }^{210} \mathrm{~Pb}_{x \mathrm{~s}}$ profile shows the regression used to calculate the sediment rate of core VD.
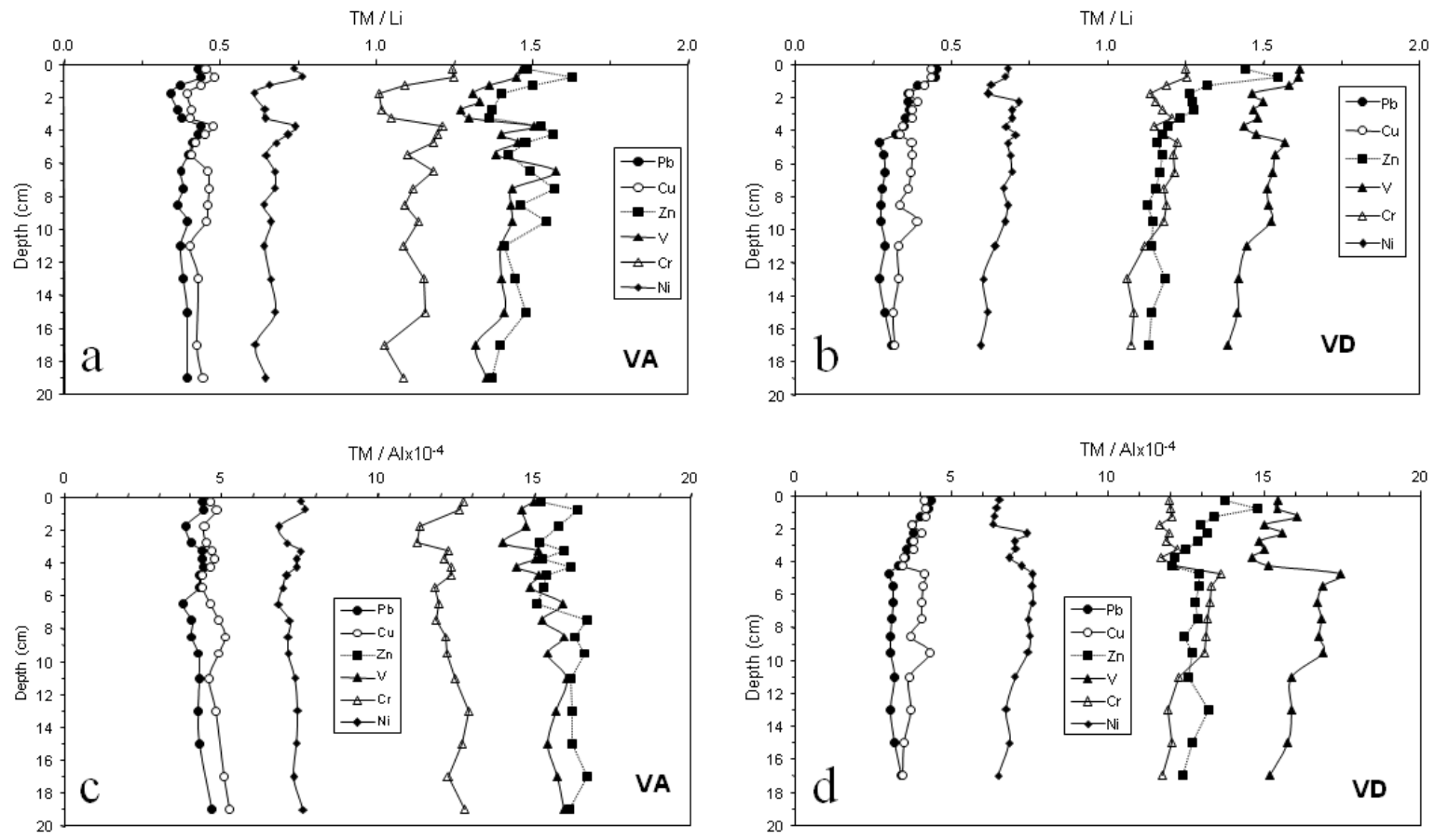

Figure S4. Trace metal $(\mathrm{V}, \mathrm{Cr}, \mathrm{Ni}, \mathrm{Cu}, \mathrm{Zn}$, and $\mathrm{Pb})$ to $\mathrm{Li}$ and $\mathrm{Al} \times 10^{-4}$ ratios (by weight) variations in sediment cores from VA (a) in the Var Canyon and VD (b) at the DYFAMED site. 


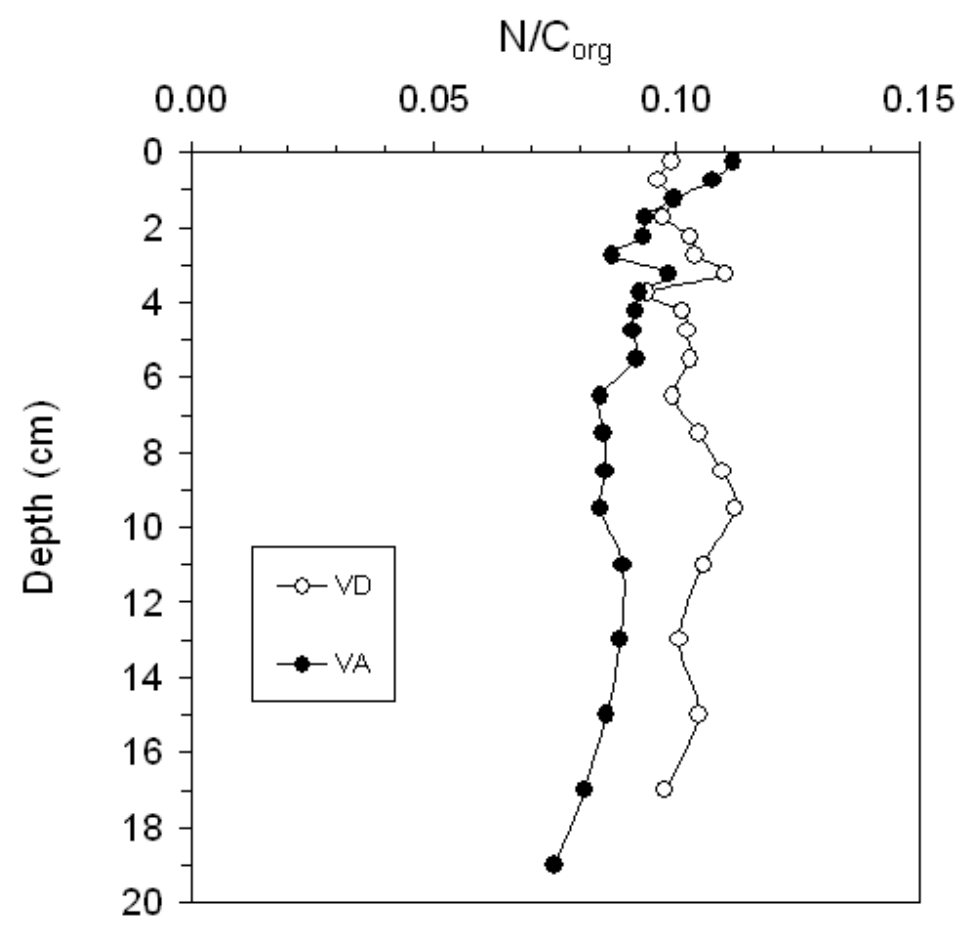

Figure S5. N/C org profiles in the sediments cores from VA in the Var Canyon and VD at the DYFAMED site.
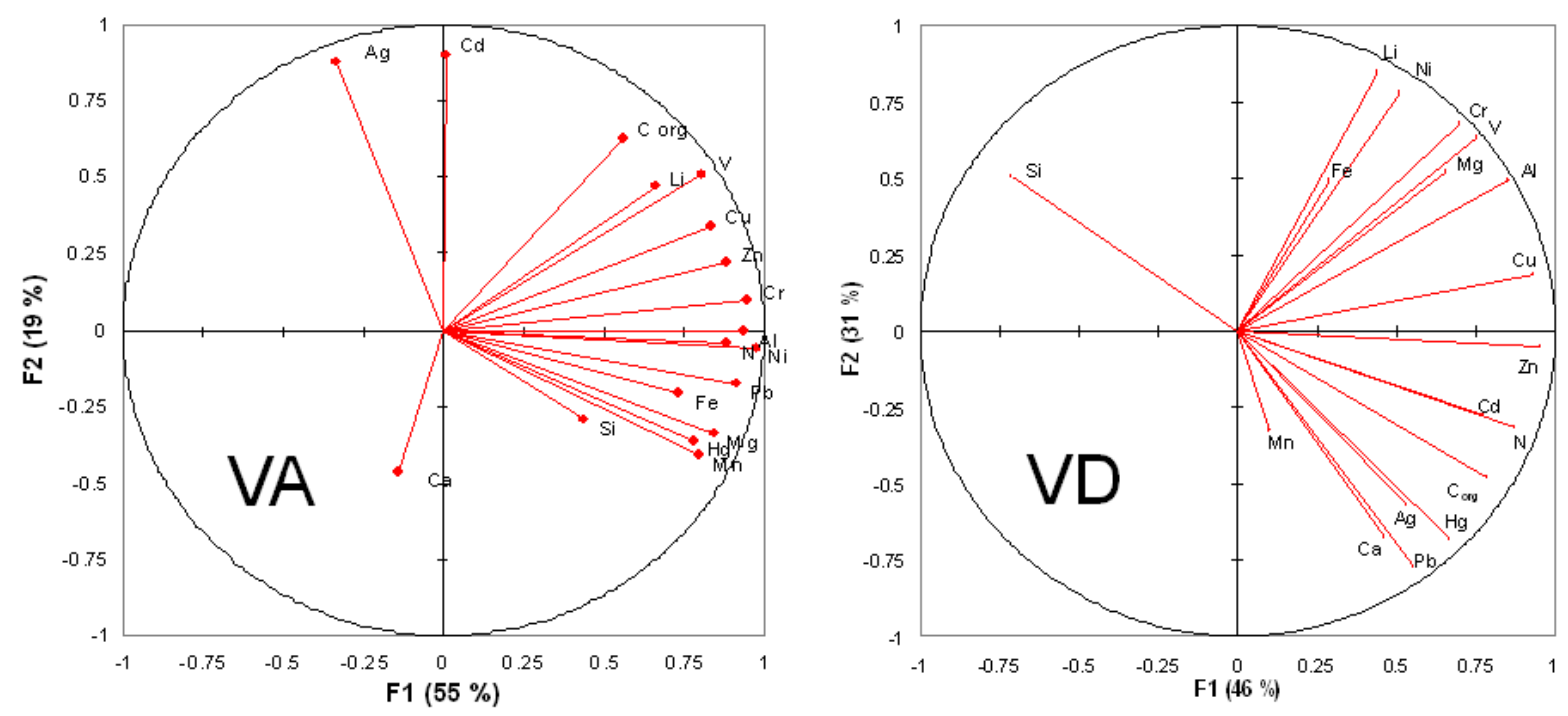

Figure S6. Above the schematic representation of the results of PCA performed independently for cores from VA (Var Canyon) and VD (DYFAMED site). Pearson correlation coefficients between chemical measurements are given in Tables S2 and S3. For both PCA factors 1 and 2 together explain the $2 / 3$ of the total variance of the data sets. For VA, factors $1(55 \%)$ is strongly correlated with $\mathrm{Al}, \mathrm{Cr}$ and $\mathrm{Ni}(\mathrm{R}>0.94)$ reasonably refer to the terrigenous component, whereas $\mathrm{Cd}$ and $\mathrm{Ag}$ strongly linked to factor $2(R>0.87)$. For VD, factor 1 is link to nitrogen $(R=0.87)$ and bioactive TMs ( $R>0.90$ for $C u$ and $\mathrm{Zn})$, suggests biomaterial, whereas factor 2 suggest a terrigenous particles $(\mathrm{R}>0.78$ for $\mathrm{Ni}$ and $\mathrm{Li})$. 

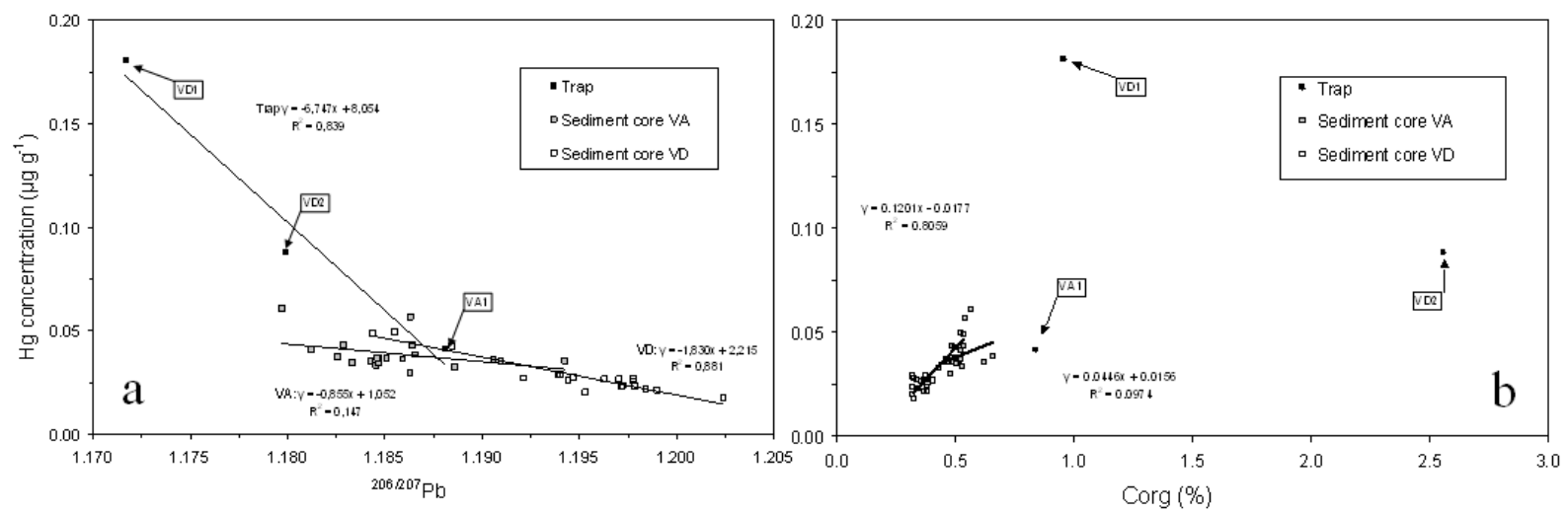

Figure S7. Relationship between $\mathrm{Hg}$ concentration and ${ }^{206 / 207} \mathrm{~Pb}$ ratio and organic carbon $\left(\mathrm{C}_{\text {org }}\right)$ in the deposited sediments and particles from traps. VA: sediments cored in the Var Canyon; VD: sediment cored at the DYFAMED site. Significant $(p<0.01)$ correlations between $\mathrm{Hg}$ and ${ }^{206 / 207} \mathrm{~Pb}$ ratio were observed for the material in the sediment traps $\left(R^{2}=0.84\right)$ and for sediment in VD core $\left(R^{2}=0.88\right)$. Significant $(p<0.01)$ correlations between $\mathrm{Hg}$ and $\mathrm{C}_{\text {org }}$ was observed for the sediment in VD core $\left(R^{2}=0.81\right)$.

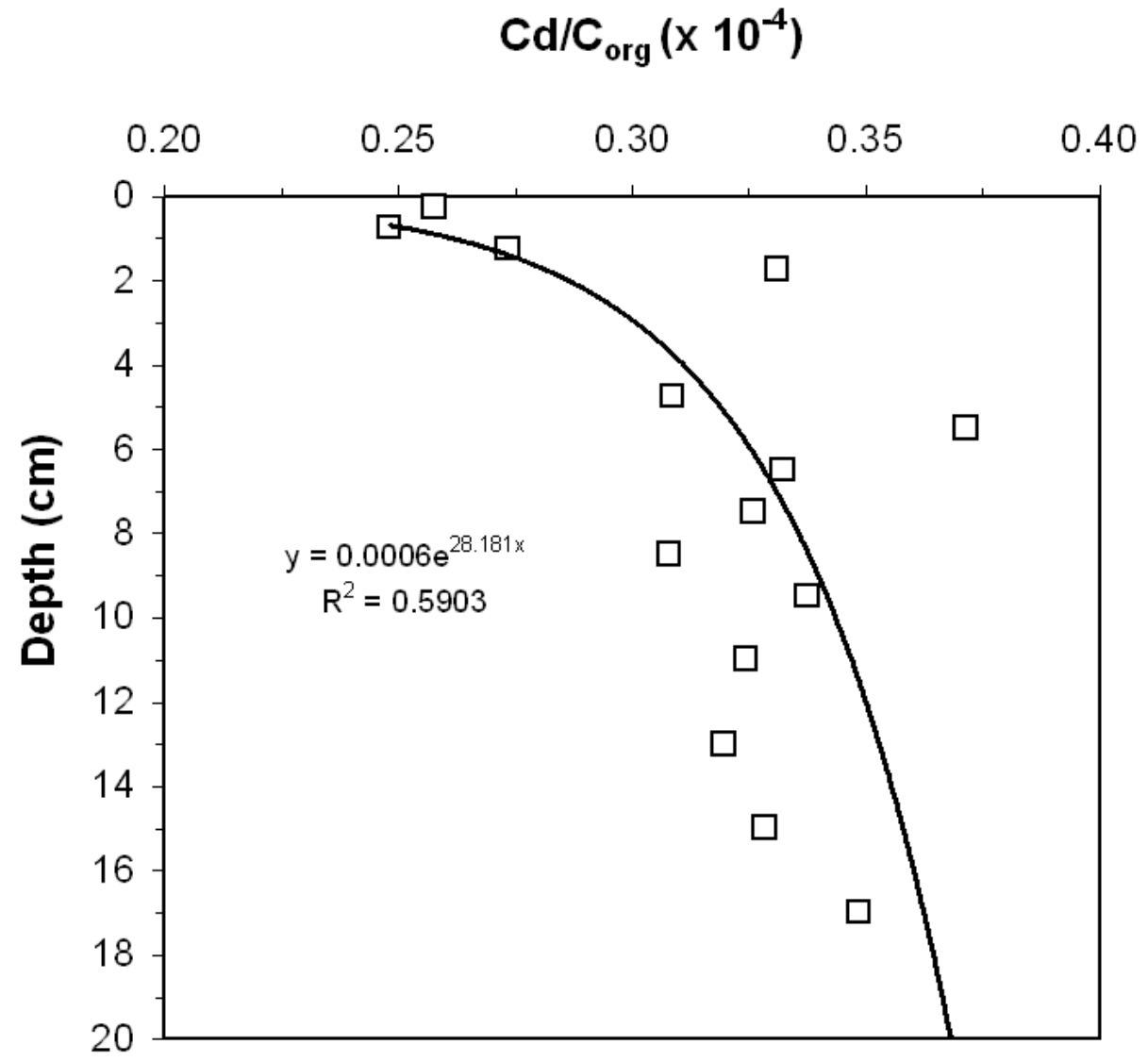

Figure S8. $C d / C_{\text {org }}$ ratio (weight) variations in the sediment core from VD at the DYFAMED site (the turbiditic 


\begin{tabular}{|c|c|c|c|c|c|c|c|c|c|c|c|c|}
\hline \multirow[b]{3}{*}{ Li } & \multirow[b]{3}{*}{$\mu g / g$} & \multicolumn{3}{|c|}{ MESS-2 } & \multicolumn{4}{|c|}{ MESS-3 } & \multicolumn{3}{|c|}{ BCSS-1 } & \multirow[t]{2}{*}{$\begin{array}{c}\text { detection } \\
\text { limit }\end{array}$} \\
\hline & & \multicolumn{2}{|c|}{ certified values } & this work & \multicolumn{3}{|c|}{ certified values } & \multirow{2}{*}{$\begin{array}{c}\text { this work } \\
66\end{array}$} & \multirow{2}{*}{\multicolumn{2}{|c|}{$\begin{array}{c}\text { certified values } \\
\text { N.A. }\end{array}$}} & \multirow{2}{*}{$\begin{array}{c}\text { this work } \\
36\end{array}$} & \\
\hline & & 73.9 & $\pm \quad 0.7$ & & 73.6 & \pm & 5.2 & & & & & 0.83 \\
\hline V & $\mu g / g$ & 252 & 10 & & 243 & \pm & 10 & 234 & $93.4 \pm$ & $\pm \quad 4.9$ & 85 & 1.67 \\
\hline $\mathrm{Cr}$ & $\mu g / g$ & 106 & 8 & & 105 & \pm & 4 & 99 & 123 & 14 & 100 & 1.67 \\
\hline Mn & $\mu g / g$ & 365 & 21 & & 324 & \pm & 12 & 307 & 229 & 15 & 222 & 0.67 \\
\hline $\mathrm{Ni}$ & $\mu g / g$ & 49.3 & 1.8 & & 46.9 & \pm & 2.2 & 44.8 & $55.3 \pm$ & 3.6 & 51.4 & 0.17 \\
\hline $\mathrm{Cu}$ & $\mu g / g$ & 39.3 & \pm 2 & & 33.9 & \pm & 1.6 & 34.1 & $18.5 \pm$ & 2.7 & 19.1 & 0.83 \\
\hline Zn & $\mu \mathrm{g} / \mathrm{g}$ & 172 & $\pm \quad 16$ & & 159 & \pm & 8 & 149 & $119 \pm$ & 12 & 104 & 0.83 \\
\hline $\mathrm{Ag}$ & $\mu \mathrm{g} / \mathrm{g}$ & 0.18 & $\pm \quad 0.02$ & & 0.18 & \pm & 0.02 & 0.22 & $0.11 \pm$ & 0.03 & 0.13 & 1.67 \\
\hline Cd & $\mu \mathrm{g} / \mathrm{g}$ & 0.24 & \pm 0.01 & & 0.24 & \pm & 0.01 & 0.26 & $0.25 \pm$ & 0.04 & 0.29 & 0.01 \\
\hline $\mathbf{P b}$ & $\mu \mathrm{g} / \mathrm{g}$ & 21.9 & 1.2 & & 21.1 & \pm & 0.7 & 23 & $22.7 \pm$ & 3.4 & 23.4 & 0.83 \\
\hline $\mathrm{Hg}$ & $\mu g / g$ & 0.092 & \pm 0.002 & $0.092 \pm 0.009$ & 0.091 & \pm & 0.009 & 0.090 & & A. & N.A. & 0.007 \\
\hline $\mathrm{Mg}$ & $\%$ & & V.A. & & 1.6 & & & 1.70 & $1.47 \pm$ & $\pm \quad 0.14$ & 1.33 & 0.40 \\
\hline Al & $\%$ & 8.57 & \pm 0.26 & & 8.59 & \pm & 0.23 & 8.40 & 6.26 & 0.22 & 6.14 & 0.20 \\
\hline Si & $\%$ & 27.8 & $\pm \quad 1.1$ & & 27 & & & 26.5 & 30.9 & 0.5 & 30.9 & 0.40 \\
\hline $\mathrm{Ca}$ & $\%$ & & V.A. & & 1.47 & \pm & 0.06 & 1.54 & 0.54 & 0.05 & N.A. & 0.40 \\
\hline $\mathrm{Fe}$ & $\%$ & 4.35 & $\pm \quad 0.22$ & & 4.34 & \pm & 0.11 & 4.18 & 3.29 & 0.1 & 3.10 & 0.01 \\
\hline
\end{tabular}

Table S1. Quality control showing certified reference material MESS-2, MESS-3 and BCSS-1, our measured values and detection limits. 
Table S2. Correlation coefficients (Pearson) for VA and VD cores. A value $\geq 0.56$ is required for a significance level of $p=0.01$ with a degree of freedom $=18(n=20)$.

\begin{tabular}{|c|c|c|c|c|c|c|c|c|c|c|c|c|c|c|c|c|c|c|}
\hline VA & $\mathrm{N}$ & Corg & $\mathrm{Li}$ & V & $\mathrm{Cr}$ & $\mathrm{Mn}$ & $\mathrm{Ni}$ & $\mathrm{Cu}$ & $\mathrm{Zn}$ & $\mathrm{Ag}$ & $\mathrm{Cd}$ & $\mathrm{Pb}$ & $\mathrm{Hg}$ & $\mathrm{Mg}$ & Al & Si & $\mathrm{Ca}$ & $\mathrm{Fe}$ \\
\hline $\mathrm{N}$ & 1 & .574 & 0.419 & 0.719 & 0.864 & 0.738 & 0.805 & 0.630 & 0.693 & -0.350 & -0.011 & 0.786 & 0.868 & 0.813 & 0.804 & 0.209 & 0.142 & 0.506 \\
\hline Corg & 0.574 & 1 & 0.530 & 0.751 & 0.613 & 0.211 & 0.469 & 0.692 & 0.543 & 0.282 & 0.470 & 0.504 & & 0.225 & 0.438 & -0.084 & -0.501 & .159 \\
\hline $\mathrm{Li}$ & 0.419 & 0.530 & 1 & 0.720 & 0.603 & 0.252 & 0.650 & 0.693 & 0.751 & 0.324 & 0.354 & 0.554 & & 0.432 & 99 & & -0.084 & 0.637 \\
\hline V & 0.719 & 0.751 & .720 & 1 & 0.849 & 0.467 & 741 & 307 & 0.761 & 0.162 & & & & & & & & \\
\hline $\mathrm{Cr}$ & 864 & 613 & .603 & 0.849 & 1 & 0.696 & 41 & & 0.806 & 93 & 79 & 899 & & & & & & \\
\hline $\mathrm{Mn}$ & 0.738 & 0.211 & 0.252 & 0.467 & 0.696 & 1 & & & 0.679 & & & & & & & & & \\
\hline $\mathrm{Ni}$ & & 0.469 & 0.650 & 0.741 & & & 1 & & 0.838 & & & & & & & & & \\
\hline $\mathrm{Cu}$ & 0.630 & 0.692 & 0.693 & 0.807 & 0.783 & 0.597 & 0.803 & 1 & 0.861 & -0.002 & 0.329 & 0.702 & 0.444 & 0.555 & 0.723 & 0.415 & -0.250 & 0.549 \\
\hline $\mathrm{Zn}$ & 0.693 & 0.543 & 0.751 & 0.761 & 0.806 & 0.679 & 0.838 & 0.861 & 1 & -0.063 & 0.234 & 0.729 & 0.540 & 0.648 & 0.837 & 0.336 & -0.134 & 0.660 \\
\hline $\mathrm{Ag}$ & -0.350 & 0.282 & 0.324 & 0.162 & -0.293 & -0.623 & -0.386 & -0.002 & -0.063 & 1 & 0.801 & -0.578 & -0.654 & -0.495 & -0.247 & -0.378 & -0.137 & -0.291 \\
\hline $\mathrm{Cd}$ & -0.011 & 0.470 & 0.354 & 0.512 & 0.079 & -0.306 & -0.069 & 0.329 & 0.234 & 0.801 & 1 & -0.336 & -0.252 & -0.218 & 0.061 & -0.260 & 277 & -0.160 \\
\hline $\mathrm{Pb}$ & & & 0.554 & 0.638 & & & & & 0.729 & -0.578 & & $\perp$ & & & & & & 06 \\
\hline $\mathrm{Hg}$ & & & 0.135 & 0.468 & & & & & 0.540 & -0.654 & & & 1 & & & & & \\
\hline $\mathrm{Mg}$ & 0.813 & 0.225 & 0.432 & 0.515 & 0.701 & 0.824 & & & 0.648 & -0.495 & -0.218 & 0.662 & & & 0.920 & & & 823 \\
\hline $\mathrm{Al}$ & 0.804 & 0.438 & 0.699 & 0.783 & 0.857 & 0.765 & 0.894 & 0.723 & 0.837 & -0.247 & 0.061 & 0.779 & 0.677 & 0.920 & 1 & 0.263 & 0.082 & 0.825 \\
\hline Si & 0.209 & -0.084 & 0.253 & 0.143 & 0.380 & 0.422 & 0.559 & 0.415 & 0.336 & -0.378 & -0.260 & 0.521 & 0.329 & 0.335 & 0.263 & 1 & -0.152 & 0.310 \\
\hline $\mathrm{Ca}$ & -0.142 & -0.501 & -0.084 & -0.320 & -0.337 & 0.216 & -0.211 & -0.250 & -0.134 & -0.137 & -0.277 & -0.310 & -0.141 & 0.284 & 0.082 & -0.152 & 1 & 0.319 \\
\hline $\mathrm{Fe}$ & 0.506 & 0.159 & 0.637 & 0.404 & 0.565 & 0.563 & 0.744 & 0.549 & 0.660 & -0.291 & -0.160 & 0.606 & 0.488 & 0.823 & 0.825 & 0.310 & 0.319 & 1 \\
\hline
\end{tabular}




\begin{tabular}{|c|c|c|c|c|c|c|c|c|c|c|c|c|c|c|c|c|c|c|}
\hline VD & $\mathrm{N}$ & C org & $\mathrm{Li}$ & V & $\mathrm{Cr}$ & $\mathrm{Mn}$ & $\mathrm{Ni}$ & $\mathrm{Cu}$ & $\mathrm{Zn}$ & $\mathrm{Ag}$ & $\mathrm{Cd}$ & $\mathrm{Pb}$ & $\mathrm{Hg}$ & $\mathrm{Mg}$ & $\mathrm{Al}$ & Si & $\mathrm{Ca}$ & $\mathrm{Fe}$ \\
\hline $\mathrm{N}$ & 1 & 0.964 & 0.116 & 0.449 & 0.372 & -0.058 & 0.103 & 0.689 & 0.848 & 0.606 & 0.664 & 0.734 & 0.853 & 0.509 & 0.579 & -0.765 & 0.510 & 0.099 \\
\hline C org & 0.964 & 1 & -0.051 & 0.294 & 0.209 & -0.061 & -0.071 & 0.571 & 0.784 & 0.647 & 0.621 & 0.787 & 0.898 & 0.357 & 0.416 & -0.818 & 0.602 & -0.052 \\
\hline $\mathrm{Li}$ & 0.116 & -0.051 & 1 & 0.901 & 0.867 & -0.226 & 0.831 & 0.559 & 0.406 & -0.325 & 0.182 & -0.463 & -0.346 & 0.692 & 0.802 & 0.028 & -0.353 & 0.398 \\
\hline V & 0.449 & 0.294 & 0.901 & 1 & 0.977 & -0.161 & 0.871 & 0.830 & 0.683 & 0.060 & 0.438 & -0.099 & 0.055 & 0.782 & 0.948 & -0.255 & -0.076 & 0.463 \\
\hline $\mathrm{Cr}$ & 0.372 & 0.209 & 0.867 & 0.977 & 1 & -0.185 & 0.925 & 0.801 & 0.612 & 0.052 & 0.369 & -0.141 & 0.018 & 0.771 & 0.921 & -0.141 & -0.119 & 0.523 \\
\hline Mn & -0.058 & -0.061 & -0.226 & -0.161 & -0.185 & 1 & -0.003 & 0.125 & 0.152 & 0.059 & 0.385 & 0.417 & 0.184 & -0.233 & -0.025 & -0.274 & 0.439 & 0.023 \\
\hline $\mathrm{Ni}$ & 0.103 & -0.071 & 0.831 & 0.871 & 0.925 & -0.003 & 1 & 0.656 & 0.417 & -0.167 & 0.237 & -0.288 & -0.192 & 0.718 & 0.815 & 0.031 & -0.192 & 0.589 \\
\hline $\mathrm{Cu}$ & 0.689 & 0.571 & 0.559 & 0.830 & 0.801 & 0.125 & 0.656 & 1 & 0.867 & 0.522 & 0.744 & 0.378 & 0.501 & 0.629 & 0.869 & -0.498 & 0.256 & 0.369 \\
\hline $\mathrm{Zn}$ & 0.848 & 0.784 & 0.406 & 0.683 & 0.612 & 0.152 & 0.417 & 0.867 & 1 & 0.516 & 0.751 & 0.561 & 0.660 & 0.583 & 0.791 & -0.684 & 0.457 & 0.224 \\
\hline $\mathrm{Ag}$ & 0.606 & 0.647 & -0.325 & 0.060 & 0.052 & 0.059 & -0.167 & 0.522 & 0.516 & 1 & 0.619 & 0.694 & 0.774 & -0.153 & 0.151 & -0.516 & 0.488 & 0.013 \\
\hline $\mathrm{Cd}$ & 0.664 & 0.621 & 0.182 & 0.438 & 0.369 & 0.385 & 0.237 & 0.744 & 0.751 & 0.619 & 1 & 0.594 & 0.613 & 0.245 & 0.511 & -0.692 & 0.486 & -0.122 \\
\hline $\mathrm{Pb}$ & 0.734 & 0.787 & -0.463 & -0.099 & -0.141 & 0.417 & -0.288 & 0.378 & 0.561 & 0.694 & 0.594 & 1 & 0.941 & -0.013 & 0.114 & -0.713 & 0.772 & -0.082 \\
\hline $\mathrm{Hg}$ & 0.853 & 0.898 & -0.346 & 0.055 & 0.018 & 0.184 & -0.192 & 0.501 & 0.660 & 0.774 & 0.613 & 0.941 & 1 & 0.135 & 0.218 & -0.735 & 0.706 & -0.053 \\
\hline $\mathrm{Mg}$ & 0.509 & 0.357 & 0.692 & 0.782 & 0.771 & -0.233 & 0.718 & 0.629 & 0.583 & -0.153 & 0.245 & -0.013 & 0.135 & 1 & 0.815 & -0.228 & 0.000 & 0.362 \\
\hline Al & 0.579 & 0.416 & 0.802 & 0.948 & 0.921 & -0.025 & 0.815 & 0.869 & 0.791 & 0.151 & 0.511 & 0.114 & 0.218 & 0.815 & 1 & -0.356 & 0.103 & 0.522 \\
\hline $\mathrm{Si}$ & -0.765 & -0.818 & 0.028 & -0.255 & -0.141 & -0.274 & 0.031 & -0.498 & -0.684 & -0.516 & -0.692 & -0.713 & -0.735 & -0.228 & -0.356 & 1 & -0.808 & 0.156 \\
\hline $\mathrm{Ca}$ & 0.510 & 0.602 & -0.353 & -0.076 & -0.119 & 0.439 & -0.192 & 0.256 & 0.457 & 0.488 & 0.486 & 0.772 & 0.706 & 0.000 & 0.103 & -0.808 & 1 & -0.199 \\
\hline $\mathrm{Fe}$ & 0.099 & -0.052 & 0.398 & 0.463 & 0.523 & 0.023 & 0.589 & 0.369 & 0.224 & 0.013 & -0.122 & -0.082 & -0.053 & 0.362 & 0.522 & 0.156 & -0.199 & 1 \\
\hline
\end{tabular}


Table S3. Cosinus square for the PCAs. In bolt the highest $\cos ^{2}$ for each variable. $\operatorname{Cos}^{2}$ refer to the representativeness of a variable on $\mathrm{F} 1$ or $\mathrm{F} 2$ axis.

\begin{tabular}{|c|c|c|c|c|c|}
\hline \multicolumn{3}{|c|}{ VA : $\operatorname{Cos}^{2}$ of variables } & \multirow{2}{*}{\multicolumn{3}{|c|}{ VD : $\operatorname{Cos}^{2}$ of variables }} \\
\hline & $\mathrm{F} 1$ & F2 & & & \\
\hline$N$ & 0.77 & 0.00 & & $\mathrm{~F} 1$ & $\mathrm{~F} 2$ \\
\hline $\mathrm{C}_{\text {org }}$ & 0.32 & 0.40 & $\mathrm{~N}$ & 0.76 & 0.10 \\
\hline $\mathrm{Li}$ & 0.44 & 0.22 & $\mathrm{C}_{\text {org }}$ & 0.62 & 0.23 \\
\hline V & 0.64 & 0.26 & $\mathrm{Li}$ & 0.19 & 0.71 \\
\hline $\mathrm{Cr}$ & 0.90 & 0.01 & V & 0.57 & 0.40 \\
\hline $\mathrm{Mn}$ & 0.63 & 0.17 & $\mathrm{Cr}$ & 0.49 & 0.46 \\
\hline $\mathrm{Ni}$ & 0.95 & 0.00 & $\mathrm{Mn}$ & 0.01 & 0.11 \\
\hline $\mathrm{Cu}$ & 0.70 & 0.12 & $\mathrm{Ni}$ & 0.26 & 0.61 \\
\hline $\mathrm{Zn}$ & 0.78 & 0.05 & $\mathrm{Cu}$ & 0.86 & 0.03 \\
\hline $\mathrm{Ag}$ & 0.11 & 0.76 & $\mathrm{Zn}$ & 0.91 & 0.00 \\
\hline $\mathrm{Cd}$ & 0.00 & 0.80 & $\mathrm{Ag}$ & 0.28 & 0.32 \\
\hline $\mathrm{Pb}$ & 0.78 & 0.03 & $\mathrm{Cd}$ & 0.60 & 0.07 \\
\hline $\mathrm{Hg}$ & 0.61 & 0.13 & $\mathrm{~Pb}$ & 0.31 & 0.60 \\
\hline $\mathrm{Mg}$ & 0.70 & 0.12 & $\mathrm{Hg}$ & 0.45 & 0.46 \\
\hline $\mathrm{Al}$ & 0.87 & 0.00 & $\mathrm{Mg}$ & 0.43 & 0.27 \\
\hline $\mathrm{Si}$ & 0.19 & 0.08 & Al & 0.72 & 0.24 \\
\hline $\mathrm{Ca}$ & 0.02 & 0.21 & $\mathrm{Si}$ & 0.51 & 0.26 \\
\hline $\mathrm{Fe}$ & 0.54 & 0.04 & $\mathrm{Ca}$ & 0.22 & 0.45 \\
\hline & & & $\mathrm{Fe}$ & 0.08 & 0.24 \\
\hline
\end{tabular}

